STUDIA POLONIJNE

T. 40. LUBLIN 2019

DOI: http://dx.doi.org/10.18290/sp.2019.15

JOANNA OKARMA

\title{
TOWARZYSTWO HISTORYCZNO-LITERACKIE I BIBLIOTEKA POLSKA W PARYŻU: DOŚWIADCZENIE WYMIANY MIĘDZYBIBLIOTECZNEJ W ROKU 2008/2009
}

\author{
TOWARZYSTWO HISTORYCZNO-LITERACKIE / BIBLIOTEKA POLSKA \\ W PARYŻU - TŁO HISTORYCZNE*
}

W sercu Europy Zachodniej, we francuskiej stolicy świata kultury, na jednej z dwu wysp utworzonych przez Sekwanę: Wyspie Świętego Ludwika / L'Île de Saint Louis $^{1}$ o powierzchni 11 ha, zasiedlonej od XVII wieku, znajduje się od $1853 \mathrm{r}$. nieopodal Pont de la Tournelle, łączącym ją z lewobrzeżną częścią miasta, przy 6, Quai d'Orléans Biblioteka Polska w Paryżu / Bibliothèque Polonaise de Paris (BPP; strona oficjalna THL/BPP: http://www.bibliotheque-polonaise-paris-shlp.fr/). Choć Wyspa obecną nazwę nosi od 1725 r., to paryżanie nazywali ją wyspą pałaców, zwanych hotelami. Od połowy XIX wieku chętnie osiedlali się tu francuscy pisarze i artyści, z czasem dołączyli do nich przedstawiciele innych narodowości, także polskiej. Wspomnijmy tu Charles'a Baudelaire'a, mieszkającego w latach 1842-1845 przy 22, Quai de Béthune, a potem kolejno przy 15 i 17, Quai d'Anjou, czy rzeźbiarkę Camille Claudel - siostrę poety i dramaturga Paula Claudela - mieszkającą na Wyspie na przełomie XIX/XX wieku. Spośród Polaków wymieńmy chociażby księcia Adama Jerzego Czartoryskiego zamieszkującego z rodziną w Hôtelu Lambert przy 2, rue Saint-Louis-en-l'lle (ulicy krzyżującej się z Quai d'Anjou przez ponad 130 lat), pierwszą kobietę naukowca Marię Skłodowską-Curie przebywają-

Mgr JoAnNA OKARMA - Warszawa; e-mail: joanna.okarma@wp.pl

* Składam serdeczne podziękowania pani Ewie Rutkowskiej, kustosz z THL/BPP, za wyrażenie swoich spostrzeżeń, życzliwe sugestie i wskazane mi źródło w trakcie pracy nad tekstem.

${ }^{1}$ Przez wcześniejsze wieki, razem z L'Île de Notre Dame / dziś: L'île de la Cité, była dziewiczą Wyspą Krowią / L'Ŷle aux Vaches: niezabudowana i niepołączona ani z sąsiednią L'île de Notre Dame, ani z prawobrzeżną Sekwaną żadnym mostem (tł. własne). Por. A. NiEwĘGŁowski, Brève histoire de l'Hôtel 6, quai d'Orléans, [w:] Bibliothèque Polonaise de Paris: colloque de 20-21 septembre 2004, réd. M. Stęplewska, Cracovie 2008, s. 90. Zob. F. ZIEJKA, Skarby kultury polskiej na Wyspie Świętego Ludwika w Paryżu, „Acta Universitatis Wratislaviensis”. Prace Literackie 2015, nr 55, s. 17-33. 
cą w latach 1912-1934 przy 36, Quai de Béthune. Na Wyspie miała swoją siedzibę „Libella” Kazimierza i Zofii Romanowiczów, a właściwie stanowiły ją cztery przedsiębiorstwa przy rue Saint-Louis-en-l'Ile: księgarnia Libella (funkcjonowała w latach 1946-1993), wydawnictwo Libella (1956-1993), wydawnictwo płytowe Ballada-Pavillon Record-Company (1950-1968) oraz Galeria Lambert (1959-1993). Owa „instytucja spełnionych nadziei” przez prawie 50 lat była ważnym ośrodkiem polskiego życia kulturalnego i literackiego Polonii francuskiej ${ }^{3}$.

W najbliższej okolicy od Wyspy Świętego Ludwika na Pont de la Tournelle znajduje się od 1928 r. wzniesiona na cokole figura św. Genowefy - patronki Paryża - autorstwa Paula Landowskiego, syna polskiego uchodźcy z 1863 r. Edwarda ${ }^{4}$, mająca w zasięgu wzroku Bibliotekę Polską, która nazywana jest dzisiaj żywym pomnikiem polskiej kultury i emigracji, a nie figura św. Genowefy ${ }^{5}$. W niniejszym artykule, oprócz przedstawienia historii Towarzystwa Historyczno-Literackiego zarządzającego Biblioteką, która nigdy nie miała osobowości prawnej, podzielę się moimi doświadczeniami.

Po upadku powstania listopadowego 1831 r., we Francji, a głównie w Paryżu i okolicach pozostała liczna grupa polskich emigrantów politycznych ${ }^{6}$. W $1838 \mathrm{r}$. założyli Bibliotekę Polską w Paryżu, pozostawiając swój trwały ślad i znaczenie, aż do czasów współczesnych ${ }^{7}$. Silna tożsamość narodowa, szacunek i tęsknota za własnym krajem skłaniały Polaków z czasów Wielkiej Emigracji do solidarności i patriotyzmu. Głównym miejscem spotkań z polską społecznością, polską myślą polityczną i kulturą stała się Biblioteka Polska przy 10, rue Duphot. Z powodu roz-

2 Por. A. KŁossowski, Instytucja spetnionej nadziei: Paryska Libella i Galeria Lambert Zofii i Kazimierza Romanowiczów: [katalog] wystawy 6 grudnia 1994 - 15 stycznia 1995, Pałac Rzeczypospolitej, Warszawa 1994/1995, s. 35, [za:] F. ZIEJKA, Skarby kultury polskiej, s. 19.

${ }^{3}$ Ze względu na podeszły wiek i brak spadkobierców pp. Romanowiczowie zdecydowali o likwidacji swojej placówki, a archiwum Libelli i Galerii Lambert przekazali do powstałego na Uniwersytecie Mikołaja Kopernika w Toruniu - Archiwum Emigracji, [za:] F. ZIEJKA, Skarby kultury polskiej, s. 19.

${ }^{4}$ Rzeźba w kamieniu św. Genowefy została wpisana na listę światowego dziedzictwa kultury UNESCO w 1991 r., [za:] F. ZIEJKA, Skarby kultury polskiej, s. 19.

${ }^{5}$ Por. K. SeroKA, Biblioteka Polska w Paryżu - polskie miejsce pamięci w Paryżu. Referat wygłoszony na konferencji naukowej „Miejsca pamięci w świadomości współczesnego człowieka” w dn. 10 maja 2013 r. na Uniwersytecie Mikołaja Kopernika w Toruniu.

${ }^{6}$ Około 6 tys. polskich emigrantów w różnym wieku. Por. L. Talko, Biblioteka Polska w Paryżu, rozmowę przeprowadziła A. Ciesielska-Ribard [14 stycznia 1999 r.], „Roczniki. PAN. Stacja Naukowa w Paryżu" 2(2000), s. 161n.

${ }^{7}$ Zaznaczmy, iż w roku obchodów 100-lecia odzyskania przez Polskę niepodległości przypada 180. rocznica utworzenia Biblioteki Polskiej w Paryżu. Z tej okazji prezydent Andrzej Duda wystosował list, który został głośno odczytany podczas uroczystego kolokwium w BPP w dn. 26 października 2018 r., https:/www.prezydent.pl/aktualnosci/wypowiedzi-prezydenta-rp/inne/art,846,list-prezydenta-na-180-rocznica-utworzenia-biblioteki-polskiej-w-paryzu.html [dostęp: 26.10.2018]. 


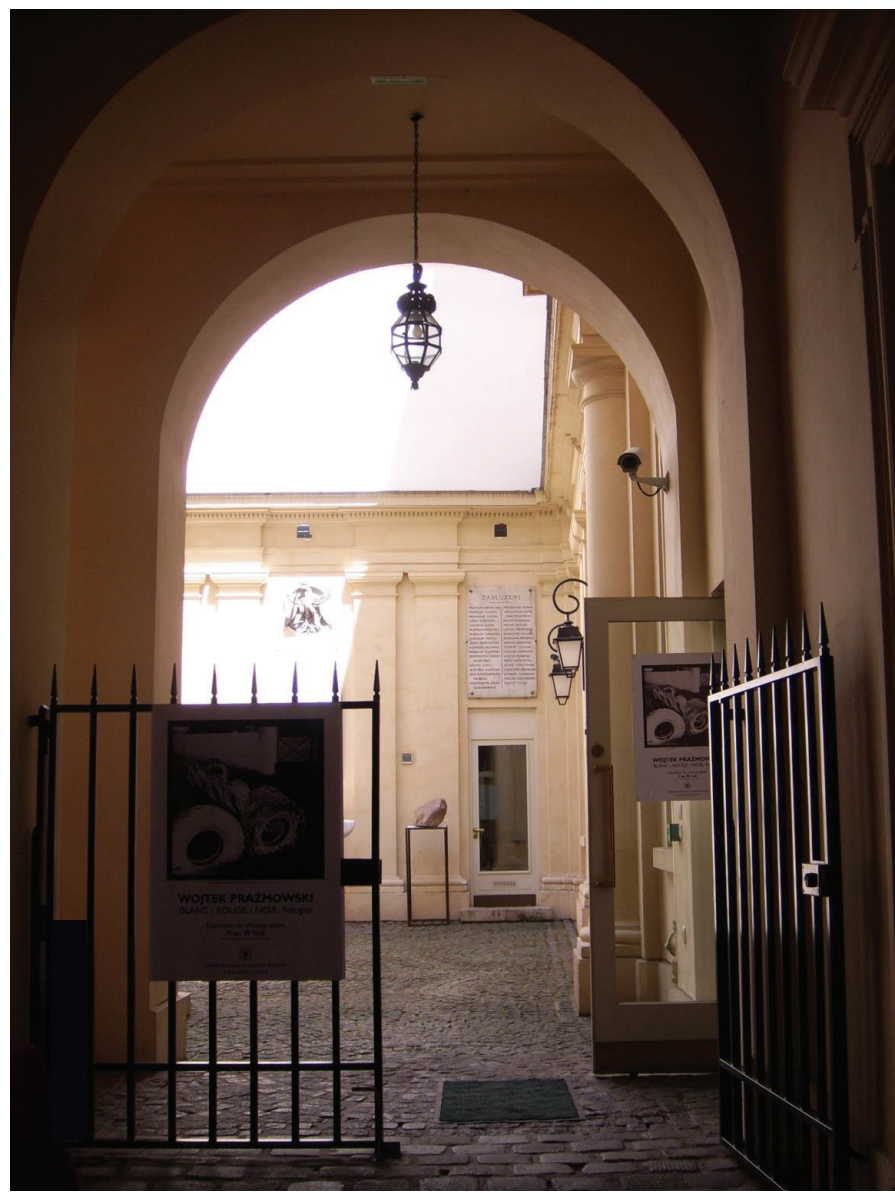

Widok na duży dziedziniec Biblioteki Polskiej w Paryżu przez mały dziedziniec z bramy głównej przy 6, Quai d'Orléans. Po obu stronach wejścia wywieszone plakaty informacyjne o wystawie fotograficznej prac Wojtka Prażmowskiego pt. Blanc / Rouge /

Noire. Pologne, zorganizowanej w dn. 11-30 maja 2009 r. Fot. J. Okarma

rastających się zbiorów pochodzących z darów osób czy rodzin polskich uchodźców we Francji, a jednocześnie zbyt ciasnych pomieszczeń, przenoszono ją z miejsca na miejsce do wynajmowanych lokali. Z czasem życie Polonii paryskiej przeniosło się na Wyspę Świętego Ludwika. Tam w 1843 r., dzięki informacji przekazanej przez Augène Delacroix i Fryderyka Chopina, książę Adam Jerzy Czartoryski nabył zrujnowany budynek Hôtel Lambert, pochodzący z początku XVII wieku, skonstruowany przez znanego architekta Louis'a Le Vau, przy 2, rue de Saint-Louis-en-l'Île. Odtąd przez ponad sto lat pełnił rolę polskiego centrum społecznego i spotkań dyplomatycznych służących promowaniu spraw polskich w Europie. 
Dopiero z zebranych przez 4 lata datków od polskich emigrantów, których zebrania podjął się Adam Mickiewicz, zakupiono w 1853 r. czteropiętrowy budynek przy 6, Quai d'Orléans, do którego przeniesiono zbiory.

Budynek ten, a raczej rezydencja pałacowa z 1655 r. pochodzi od sekretarza króla Ludwika XIV, Antoine'a Moreau. Funkcjonowanie THL/BPP przytoczę za sugestią prezesa THL, Kazimierza Piotra Lubicz-Zaleskiego ${ }^{8}$, który wyróżniał cztery okresy w działalności tej instytucji.

1. Od 1838 do 1893 r., kiedy Towarzystwo Literackie Polskie (zał. 29 kwietnia 1832 r. $)^{9}$ wraz z wyłonionymi w następnych latach Wydziałem Historycznym i Wydziałem Statystycznym oraz Towarzystwem Pomocy Naukowej (zał. w 1832 r.) na mocy aktu fundacyjnego z 24 listopada 1838 r. utworzyły Bibliotekę Polską w Paryżu, łącząc poszczególne księgozbiory i sprawując nad nią pieczę. Dla publiczności otwarto ją 24 marca następnego roku, udostępniając 2194 książek, 147 map i pewną ilość dzieł artystycznych. Wymienione instytucje połączyły się w $1854 \mathrm{r}$., tworząc Towarzystwo Historyczno-Literackie. Pomysłodawcą założenia Biblioteki Polskiej w Paryżu gromadzącej książki i dokumentację dotyczącą Polski był Francuz - Daniel de Saint-Antoine - po opublikowaniu przez "Société de civilisation" apelu do wszystkich narodów świata potępiającego spustoszenie bibliotek, m.in.: w Warszawie, Wilnie, Krzemieńcu, oraz wywiezienie przez rząd carski Mikołaja I polskich zbiorów do Petersburga. Inicjatorami zaś byli: książę Adam Jerzy Czartoryski, Adam Mickiewicz, gen. Karol Kniaziewicz, poeta Julian Ursyn Niemcewicz, historyk Karol Sienkiewicz. Odtąd THL stało się właścicielem Biblioteki, zapewniając jej codzienne funkcjonowanie ${ }^{10}$. Dekret Napoleona III z 10 czerwca 1866 r. nadał Towarzystwu rangę organizacji pożytku publicznego, które przyjęło nazwę Towarzystwo Historyczno-Literackie Polskie. Pierwszymi prezesami TLP i THL, instytucji zarządzających Biblioteką, byli: książę Adam Czartoryski w latach 1838-1861, książę Władysław Czartoryski - 1861-1893; natomiast dyrektorami BPP: Karol Sienkiewicz w latach 1839-1853, Feliks Wrotnowski - 1854 -

${ }^{8}$ Sygnuje dokumenty także jako: C. Pierre Zaleski, Kazimierz Piotr Zaleski.

9 Towarzystwo Literackie Polskie w Paryżu przyjęło strukturę na wzór Towarzystwa Warszawskiego Przyjaciół Nauk rozwiązanego w czasie represji (prezes, sekretarz, wydziały, członkostwo honorowe, korespondenci, współpracownicy polscy i francuscy). „Prezes rozwiązanego TWPN Julian Ursyn Niemcewicz został członkiem Towarzystwa Literackiego w Paryżu i stanął na czele Wydziału Historycznego". Zob. K.P. ZALESKI, Towarzystwo Historyczno-Literackie i Biblioteka Polska w Paryżu - historia i teraźniejszość, [w:] Biblioteka Polska w Paryżu - skarbnica kultury narodowej. materiaty z konferencji zorganizowanej przez Komisję Spraw Emigracji i Łączności z Polakami za Granica, 4 listopada 2014, Warszawa 2014, s. 19 (dokument elektroniczny).

${ }^{10}$ K.P. ZALeSKi, Towarzystwo Historyczno-Literackie i Biblioteka Polska w Paryżu, s. 21 (dokument elektroniczny). 
1860, Walerian Kalinka i Eustachy Januszkiewicz - 1861-1867, Bronisław Zaleski - 1867-1880, Lubomir Gadon (von Gaden) - 1880-1893. Prezesi THL ponosili odpowiedzialność za kierunek działalności Towarzystwa, za jego sprawy finansowe. Ponadto sprawowali nadzór nad funkcjonowaniem Biblioteki Polskiej i mianowali jej dyrektorów ${ }^{11}$.

Pod koniec XIX wieku aktywność członków THL wyraźnie zmalała, bowiem zmniejszyła się liczba żyjących jego członków. Z inicjatywy ówczesnego prezesa THL Władysława Czartoryskiego i sekretarza generalnego Lubomira Gadona w 1893 r. podjęto decyzję o przekazaniu własności i powierzeniu utrzymania Biblioteki Akademii Umiejętności (AU) w Krakowie. Uważano, że AU znajdująca się pod zaborem austro-węgierskim dysponuje większą autonomią w porównaniu $\mathrm{z}$ innymi instytucjami podległymi pozostałym zaborcom ${ }^{12}$.

2. Od 1893 do 1946 r., kiedy Akademia Umiejętności została właścicielem Biblioteki i zapewniła jej funkcjonowanie. Przyjęta umowa nakładała na Akademię Umiejętności (od 1918 r. Polska Akademia Umiejętności - PAU) udostępnianie zbiorów bibliotecznych, funkcjonowanie przy BPP jednostki badawczej: Stacja Naukowa. Ponadto umowa przewidywała, że funkcję dyrektora BPP sprawować będzie delegat AU, zaś w Paryżu zostanie powołany Komitet Miejscowy, składający się z członków mianowanych przez AU, czuwający na miejscu nad właściwym funkcjonowaniem BPP. W tym okresie, gdy BPP administrowała PAU, funkcje dyrektorów BPP pełnili kolejno: Józef Korzeniowski w latach 1893-1896, Konstanty Górski - 1896-1899, Władysław Mickiewicz - 1899-1926, Franciszek Pułaski 1926-1956, który pozostawał delegatem PAU jedynie w latach 1926-1946. Skład Komitetu Miejscowego od jego powstania tworzyli m.in.: Władysław Czartoryski, Lubomir Gadon, Władysław Mickiewicz, Teodor Jełowicki, Kazimierz Stryjeński, Gustaw Taube, Stanisław Badeni, Maria Curie-Skłodowska, Maria Mickiewicz (wnuczka Adama), ambasadorowie: Alfred Chłapowski, Zygmunt Lubicz-Zaleski, Juliusz Łukasiewicz ${ }^{13}$. Praktycznie Komitet Miejscowy sprawował funkcję doradczą. Po dokonaniu niezbędnych prac renowacyjno-porządkowych zabrano się do sporządzania katalogu do już dość obszernego księgozbioru, liczącego 43 tys. woluminów. Z roku na rok wzrastała frekwencja czytelników Biblioteki, w latach 1894-1913 wygłoszono w niej 71 odczytów. Kolejno pełniący funkcję dyrekto-

${ }^{11}$ K.P. Lubicz-Zaleski, Aneks. Historia zarządzania Biblioteka Polska w Paryżu, [Paryż 2013], [w:] Towarzystwo Historyczno-Literackie, Biblioteka Polska w Paryżu: zarys historii i prezentacja zbiorów, red. W. Kordaczuk, E. Kosieradzka, E. Rutkowska, Paryż-Warszawa 2014, s. 15.

12 Zob. J. Pezda, Historia Biblioteki Polskiej w Paryżu w latach 1838-1893, Kraków 2013; K. Seroka, Biblioteka Polska w Paryżu (1838-1871): studium bibliologiczne, Warszawa 2017.

${ }_{13}$ K.P. ZALESKi, Towarzystwo Historyczno-Literackie i Biblioteka Polska w Paryżu, s. 24 (dokument elektroniczny). 
ra delegata AU najstarszy syn Adama Mickiewicza - Władysław, przekazał swoje zbiory Bibliotece, w większości pamiątki ojca i po ojcu, co pozwoliło na utworzenie w 1903 r. Muzeum Adama Mickiewicza. Na mocy umowy PAU administrowała BPP, natomiast nie była zobowiązana do materialnej pomocy Bibliotece. Ta zaś nie była miejscem dość znanym ani we Francji, ani w Polsce i praktycznie z trudem zdobywała środki na swoje funkcjonowanie. Kolejny nowy dyrektor BPP - delegat PAU Franciszek Pułaski (delegat PAU jedynie w latach 1926-1946) rozpoczą bardzo energiczną działalność, aby od polskich władz pozyskać potrzebne środki na natychmiastowy remont i unowocześnienie budynku oraz planowaną reorganizację BPP (w latach 1926-1929). Zatrudnionych trzech pracowników nie zdołało uratować przed zniszczeniem 65 tys. książek i rycin w zawilgoconym i zagrzybionym budynku. Nowy profil Biblioteki stylizował ją na centrum kultury polskiej we Francji na wzór Instytutu Francuskiego w Warszawie. Postanowiono odesłać do Polski zbiory i kolekcje niezwiązane z Polską i kulturą polską, by w ten sposób uzupełnić i wzbogacić zbiory biblioteczne i muzealne w (już) wolnej i niepodległej Rzeczpospolitej. Podarowano około 60 tys. woluminów Bibliotece PAU, Bibliotece Jagiellońskiej i Bibliotece Narodowej w Warszawie, a ponadto 32 tys. rysunków i rycin, pośród których znalazło się 75 dzieł Harmenszoona van Rijn Rembrandta i 120 Albrechta Dürera.

Pewnym sukcesem dyrektora BPP na ziemi francuskiej stało się utworzenie Centre d'études polonaises (Centrum Studiów Polskich) w 1937 r. pod auspicjami: Franciszka Pułaskiego, André Mazona i prof. Zygmunta Lubicz-Zaleskiego ${ }^{14}$, w ramach którego funkcjonowały trzy katedry: Cywilizacji Polskiej - kierowana przez Paula Cazina, Polski Współczesnej - kierowana przez historyka Henriego de Montforta (https://fr.wikipedia.org/wiki/Henri_de_Montfort), Spraw Wojskowych - pod kierownictwem gen. Louisa Faure'a, a później także gen. WP Józefa Andrzeja Teslara. Na zajęcia w Centrum Studiów Polskich uczęszczali jako wolni słuchacze studenci uczelni paryskich, którym przyznawano stypendia wyjazdowe do Polski, czy wydawano rozprawy. Centrum Studiów Polskich w styczniu 1940 r.

14 Ojciec obecnego prezesa THL Kazimierza Piotra Lubicz-Zaleskiego. Zob. Z. Markiewicz, Zygmunt Lubicz-Zaleski (29 września 1882 - 15 grudnia 1967) [nekrolog], „Pamiętnik Literacki” 1969, nr 1, s. 413-414; W. ZAHORSKI, Zygmunt Lubicz-Zaleski w archiwach Towarzystwa Historyczno-Literackiego i Biblioteki Polskiej w Paryżu, [w:] Politycy i artyści: materiaty XXXVIII Sesji Statej Konferencji Muzeów, Archiwów i Bibliotek Polskich na Zachodzie, Londyn, Polski Ośrodek Społeczno-Kulturalny, 14-18 września 2016, komitet red. D. Platt, E.K. Hoffman-Jędruch, K.R. Jaworska, J. Kułakowska-Lis, M. Machlejd, Londyn-Warszawa 2017, s. 76-80; film dokumentalny o życiu Zygmunta Lubicz-Zaleskiego $Z$ dala od orkiestry, reż. i scen. Rafael Lewandowski, prod. Vertigo, Zygmunt Zaleski Stichting, Polska, 2017, zob. Zygmunt Zaleski Stichting, https://www.zygmuntzaleskistichting.com/film [dostęp: 29.04.2018]. 
włączono w struktury Uniwersytetu Polskiego Zagranicą (UPZ). Został on powołany przez prof. Oskara Haleckiego w grudniu 1939 r. w budynku Biblioteki Polskiej, trzy tygodnie po aresztowaniu przez Niemców profesorów i pracowników naukowych Uniwersytetu Jagiellońskiego w Krakowie. Wczesna kapitulacja Francji wiosną 1940 r. uniemożliwiła jego dalsze działanie. W pewnym sensie Uniwersytet reaktywowano pod zmienioną nazwą, jako Polski Uniwersytet na Obczyźnie w Londynie w $1949 \mathrm{r}$.

W gmachu Biblioteki Polskiej od września do listopada 1939 r. przeprowadzono pośpiesznie prace zabezpieczające budynek przed pociskami i chroniące zbiory przez pożarami. W grudniu 1939 r. jej działalność dostosowano tymczasowo do potrzeb rządu i administracji państwowej, udostępniając zgromadzone w Bibliotece mapy i dokumenty ${ }^{15}$. W latach $1929-1940$ odbyły się w niej 154 wykłady i spotkania tematyczne.

Tuż przed wkroczeniem Niemców do Paryża w czerwcu 1940 r., Franciszkowi Pułaskiemu wraz z grupą pracowników i wolontariuszy udało się ewakuować i ocalić od zniszczenia najcenniejszą część kolekcji. Wybrane dokumenty zabezpieczono w skrzyniach i pakach do zdeponowania, które przewieziono ośmioma transportami do kilku miejsc we Francji (lub pośrednio tam trafiły zawrócone z drogi do miejsca docelowego): do Biblioteki Uniwersyteckiej i Biblioteki Miejskiej w Tuluzie, do Biblioteki Miejskiej w Pau, przeniesione następnie do Biblioteki Uniwersyteckiej w Montpellier, do zamku hrabiny Róży Branickiej w Montrésor, do Senlis (departament Oise), do rządowego Biura Celów Wojny, do posiadłości Henriego de Montforta - sekretarza Instytutu Francji - w La Flèche (departament Sarthe). Ocalenie wszystkich zbiorów okazało się niemożliwe w relatywnie krótkim czasie i bez wystarczających środków. „Są to bezcennej wartości pamiątki narodowe, rękopisy z epoki rozbiorowej i porozbiorowej, prawie cała spuścizna rękopiśmienna Adama Mickiewicza, archiwa powstańcze i emigracyjne, zbiory kartograficzne, statystyczne i graficzne, oraz wybrane z całości zbiorów, liczących ponad 150 tys. tomów, niemal wszystkie dzieła dawne i współczesne, zawierające naukową dokumentację o Polsce, jej dziejach, kulturze i możliwościach gospodarczych" - pisał w liście Franciszek Pułaski do kard. Augusta Hlonda 16 sierpnia 1941 r., powierzając mu pod opiekę załączone do listu 99 karty zawierające: zestawienie depozytów w wymienionych bibliotekach francuskich, oryginalne kwity depozytowe, kopie korespondencji, szczegółowe wykazy każdego depozytu ${ }^{16}$.

${ }^{15}$ K.P. Zaleski, Towarzystwo Historyczno-Literackie i Biblioteka Polska w Paryżu, s. 26 (dokument elektroniczny).

16 F. Pulaski, Biblioteka Polska w Paryżu w latach 1893-1948, Paryż 1948, s. 126n. 
Zaistniała sytuacja wymagała, aby BPP dostosowała się do warunków wojny. Na pewien czas kustosz BPP, dr Czesław Chowaniec, wstąpił do tworzącego się we Francji Wojska Polskiego, a pracownicy zaczęli pracować w założonym przez dyrektora BPP na życzenie rządu polskiego Biurze Pomocy Ofiarom Wojny, mieszczącym się w budynku BPP ${ }^{17}$. Niemcy, po wkroczeniu do Paryża, czwartego dnia zajęli Bibliotekę Polską, zrabowali 780 skrzyń, z czego 766 skrzyń druków, wyposażenie zagrabili, a budynek zdewastowali ${ }^{18}$. Pomimo obecności Niemców w Paryżu, nocą na dachu BPP działała radiostacja, która wysyłała informacje do Anglii. W ciągu dnia nadajnik przechowywał nieopodal gmachu BPP w swoim mieszkaniu Jan Żarnowski - historyk sztuki, znawca malarstwa włoskiego renesansu, który współpracował z Leonem Bzylem - dozorcą Biblioteki, zatrudnionym wówczas przez F. Pułaskiego ${ }^{19}$.

BPP wznowiła swoją działalność dopiero po wyzwoleniu Paryża w 1944 r. Kierownikiem pozostał nieugięty, pracujący do końca swojego życia, F. Pułaski, zaś oddanymi pracownikami: Czesław Chowaniec, Bronisława Monkiewicz ${ }^{20}$, Wanda Borkowska, Irena Gałęzowska ${ }^{21}$ i Denise Wrotnowska ${ }^{22}$.

Zniszczenie budynku i zbiorów wywołało w Paryżu powszechne oburzenie. Francuscy przyjaciele Biblioteki w styczniu 1945 r. zorganizowali w jej gmachu zebranie dyrektorów bibliotek, archiwów i muzeów paryskich. Powołano Komitet Pomocy Bibliotece Polskiej na wzór akcji francuskiego Towarzystwa Cywilizacji

17 Por. W. Chmielewski, $W$ trosce o narodowy i niezależny charakter Biblioteki Polskiej w Pary$\dot{z} u$ w czasie drugiej wojny światowej, „Rocznik Komisji Nauk Pedagogicznych” 66(2013), s. 15-32.

18 Zob. dziennik Leona Bzyla, zarządcy budynku BPP pod okupacją Niemiec w latach 1940-1944. J. Żarnowski, F. PuŁaski, Cz. Chowaniec, La Bibliothèque Polonaise de Paris sous l'occupation allemande (1940-1944) = Biblioteka Polska $w$ Paryżu pod okupacja niemiecka (19401944), oprac. W. Zahorski, [w:] La vie quotidienne sur l'île Saint-Louis au XIXe et au début du XXe siècle dans les collections de la Société Historique et Littéraire Polonaise / Bibliothèque Polonaise de Paris = Życie codzienne na Wyspie św. Ludwika $w$ XIX i na poczatku XX wieku $w$ kolekcjach Towarzystwa Historyczno-Literackiego / Biblioteki Polskiej w Paryżu, trad. A. Czarnocka, V. Demidot, W. Zahorski, Paris 2017, s. 22-52. Opis pakowania i przejmowania zbiorów najpierw przez Niemców, a potem odzyskiwanie ich od ZSRR. Zob. H. ŁASKARZEWSKA, Wojenne losy części zbiorów paryskiej Biblioteki Narodowej, [w:] Towarzystwo Historyczno-Literackie, Biblioteka Polska w Paryżu, s. 101-103.

${ }^{19}$ K.P. ZALeSKi, Towarzystwo Historyczno-Literackie i Biblioteka Polska w Paryżu, s. 27 (dokument elektroniczny).

${ }^{20}$ Właściwie Bronisława Antonina Mońkiewiczówna (1887-1958). Por. biogram w Bazie Biogramów Biblioteki Jagiellońskiej (BBBJ), http://www.bj.uj.edu.pl/biogramy [dostęp: 29.04.2018].

${ }^{21}$ Istnieją nieścisłości co do daty urodzenia Ireny Gałęzowskiej (1891?-1977). Por. biogram w BBBJ, http://www.bj.uj.edu.pl/biogramy [dostęp: 29.04.2018].

${ }^{22}$ Niepewny rok urodzenia Denise Wrotnowskiej (1904?-2000). Por. biogram w BBBJ, http:// www.bj.uj.edu.pl/biogramy [dostęp: 29.04.2018]. 
z 1833 r. Prezesami honorowymi powstałego Komitetu byli członkowie Akademii Francuskiej: Georges Duhamel i admirał Lucien Lacaze. Ogłoszono i opublikowano apel intelektualistów francuskich na rzecz Biblioteki Polskiej w Paryżu podpisany przez 136 osób.

3. Od 1946 do 1989 r., kiedy z inicjatywy F. Pułaskiego i prof. Zygmunta Lubicz-Zaleskiego reaktywowano Towarzystwo Historyczno-Literackie, które przejęło opiekę nad Biblioteką. Reaktywowanemu THL przyświecały te same idee, co założycielom TL i BPP w XIX wieku: „pragnęło bronić wolności polskiej kultury przed wszelką opresją oraz idei Polski wolnej i niepodległej”23. Dzięki staraniom PAU udało się odzyskać większą część zagrabionych przez Niemców kolekcji w 1947 r. Niebawem doszło do sytuacji spornej z rządem PRL i wtedy okazało się, że Polska nie jest krajem ani wolnym, ani niepodległym, ani nawet demokratycznym. Powojenny komunistyczny rząd utworzył Polską Akademię Nauk (PAN), zawieszając działalność PAU, i to właśnie PAN przejął majątek PAU w $1951 \mathrm{r}$. Taki obrót sprawy wywołał wśród Polonii francuskiej oburzenie. Pierwszy wytoczony przez THL proces przeciw PAN odbył się we Francji w 1955 r. z wyrokiem korzystnym dla rządu polskiego. W 1959 r. francuskie Zgromadzenie Narodowe opowiedziało się przeważającą większością głosów za utrzymaniem niezależności BPP od komunistycznego rządu Polski Ludowej (przeciw występowało 10 posłów partii komunistycznych parlamentu francuskiego). Sąd apelacyjny potwierdził wyrok sądu pierwszej instancji w sprawie nieciągłości Towarzystwa Historyczno-Literackiego reaktywowanego po II wojnie światowej. Zmienił decyzję w sprawie PAN oświadczając, że PAN nie reprezentuje PAU sprzed II wojny światowej. Trybunał nie ustalił właściciela BPP, zaś wyznaczył jej administratora sądowego oraz potwierdził umowę dzierżawy z 1945 r. zawartą pomiędzy Franciszkiem Pułaskim - delegatem PAU - a Polskim Zjednoczeniem Rzymsko-Katolickim z Chicago. Ta organizacja podnajęła budynek Biblioteki Polskiej Towarzystwu Historyczno-Literackiemu. Po latach umowa dzierżawy została przedłużona bezpośrednio z THL, a obecna została zawarta przed administracją francuską do $2030 \mathrm{r}$.

W okresie niepewności losów i toczących się rozpraw sądowych o własność BPP w latach 1955-1959, francuski wymiar sprawiedliwości opieczętował zbiory.

Po okresie zastoju z powodu kłopotów sądowych, BPP powróciła do funkcjonowania dzięki ekipie pracowników zorganizowanej jeszcze za czasów F. Pułaskiego, jednakże jej działalność nadal była ograniczona poważnymi problemami finansowymi. W ówczesnej sytuacji bardzo pomocne okazały się subsydia ze strony: Barbary Piaseckiej-Johnson, Kongresu Polonii Amerykańskiej, papieża Jana

${ }^{23}$ K.P. Zaleski, Towarzystwo Historyczno-Literackie i Biblioteka Polska w Paryżu, s. 28 (dokument elektroniczny). 
Pawła II, który był inicjatorem powstania Funduszu Adama Mickiewicza, a później także w znacznej mierze Fundacji Karoliny Lanckorońskiej z Brzezia do 2001 r., która obecnie podjęła się donacji na rzecz innych działań PAU i nie wspiera BPP.

W omawianym okresie prezesami THL byli ${ }^{24}$ : Kamil Gronkowski w latach 1946-1949, André Poniatowski - 1949-1977, Marian Czarnecki (wiceprezes i p.o. prezesa) - 1977-1979, Eugeniusz Zaleski - 1979-1989. Funkcję dyrektora BPP w latach 1946-1989 sprawowali: Franciszek Pułaski - 1946-1956, Czesław Chowaniec - 1956-1966 (jako p.o. dyrektora BPP i w latach 1966-1968 jako dyrektor BPP), André Poniatowski - 1969-1977, Józef Handelsman - 1977-1984, Eugeniusz Zaleski - 1986-1989, Andrzej Folkierski w 1989 r. oraz p.o. dyrektora Izabela Sołyga także w 1989 r. Po śmierci F. Pułaskiego (1956) istotną rolę w zarządzaniu Biblioteką odgrywali sekretarze generalni THL: Zygmunt Lubicz-Zaleski - 19461967, Irena Gałęzowska - 1968-1974, Jerzy Mond - 1974-198925.

Wspomniany budynek Hôtelu Lambert, zakupiony niegdyś przez księcia Adama Jerzego Czartoryskiego, rodzina Czartoryskich zdecydowała się sprzedać w 1975 r. Nabył go baron Guy de Rothschild po wcześniejszej odmowie zakupu ówczesnego rządu PRL.

4. Od roku 1989 do czasów współczesnych ${ }^{26}$, poza czasem czteroletniego remontu budynku w latach 2000-2004, kiedy Biblioteka była nieczynna. Po roku 1989, kiedy państwo polskie odzyskało niezależność, prawo do samostanowienia, wolności słowa, wolnych wyborów i prawo uczenia się demokracji, THL nawiązało stosunki partnerskie z Ministerstwem Kultury i Dziedzictwa Narodowego i z Ministerstwem Spraw Zagranicznych w Polsce, które zaowocowały współpracą intelektualną i pozyskaniem środków finansowych. Od lat 90. XX wieku BPP wspiera finansowo Fundacja im. Zygmunta Lubicz-Zaleskiego w Amsterdamie, która po 2001 r. stała się głównym dostarczycielem funduszów (80\% budżetu), jednakże jej możliwości maleją z każdym rokiem.

Kilku członków PAU sprzed 1951 r. reaktywowało Akademię. PAU odzyskała w Polsce niektóre swoje dobra, chciała także przejąć na własność BPP i część odpowiedzialności za nią. Po wstępnym etapie negocjacji THL zerwało kontakty

${ }^{24}$ Prezesi i członkowie biura THL angażowali się w działalność Towarzystwa woluntarystycznie zgodnie ze statutami THL, zapewniając istnienie i funkcjonowanie Biblioteki Polskiej. Zauważmy, iż w latach 1967-1989 prezesi THL byli równocześnie dyrektorami Biblioteki Polskiej (z wyjątkiem Józefa Handelsmana, który był jedynie dyrektorem). Podwójne funkcje wypełniali społecznie, nie pobierając za nie wynagrodzenia. Zob. K.P. LuBicz-ZALeSKi, Aneks, s. 15.

${ }^{25}$ Tamże.

${ }^{26}$ K.P. Lubicz-Zaleski, Biblioteka Polska w Paryżu, tł. z jęz. franc. K. Rutkowski, http://www. bibliotheque-polonaise-paris-shlp.fr/medias/articleCPZtraductionpolonaise.pdf [dostęp: 29.10.2009]; K.P. LuBiCZ-ZALESKI, Aneks, s. 15-16. 
z PAU, aż do 1999 r., kiedy odbyły się nowe wybory do Rady THL. I tak od roku 1989 prezesami THL byli: Andrzej Folkierski - 1989-1993, Leszek Talko - 19932003 (w latach 1989-1992 wiceprezes THL), Kazimierz Piotr Lubicz-Zaleski nieprzerwanie od 2003 r. po dzień dzisiejszy. Dyrektorami BPP w tym okresie byli: ambasador Andrzej Krzeczunowicz - 1989-1992, Leszek Talko przez dwie kadencje - 1992-1999, prof. Kazimierz Piotr Lubicz-Zaleski - 1999-2007 (jednocześnie wiceprezes THL w latach 1999-2003), Danuta Dubois - od listopada 2007 do 31 grudnia 2012 r., od 2013 r. znowu K.P. Lubicz-Zaleski ${ }^{27}$. W codziennej pracy prezesa THL / dyrektora BPP wspierają członkowie Rady Administracyjnej THL, a obsługę zapewnia biuro THL.

Pracująca Rada THL pod przewodnictwem prof. Lubicz-Zaleskiego dokonała szczegółowego oglądu stanu budynku, stwierdzając, że odpadający sufit, silna deformacja wielu belek stropowych stanowią niebezpieczeństwo dla przebywających w nim ludzi. Ponadto pomieszczenia na piętrach, w których były gromadzone zbiory, są przeciążone, a piwnice ogromnie zawilgocone, co stało się przyczyną całkowitego zniszczenia tysięcy książek i zagrzybienia cennych rękopisów, starodruków, rycin i rysunków ${ }^{28}$.

Główni sponsorzy, do których zwrócono się z prośbą o udzielenie pomocy finansowej na remont, zażądali prawnego uregulowania sprawy własności nieruchomości i zbiorów. Wstępna analiza prawna wykazała, że THL nie ma szans na przejęcie własności budynku i zbiorów BPP zgromadzonych do 1939 r., natomiast posiada je reaktywowana przez poprzednich członków PAU w Krakowie, co stanowi nowy fakt wobec uprawomocnionego orzeczenia trybunału apelacyjnego z $1959 \mathrm{r}$.

W efekcie tych konstatacji wiceprzewodniczący THL K.P. Lubicz-Zaleski ${ }^{29}$ złożył wniosek do Rady THL przez ręce prezesa Leszka Talko w 1999 r., która powzięła

27 Należy zaznaczyć, że od 1992 r. do października 2007 r. i od 2013 r. prezesi lub wiceprezesi THL byli jednocześnie dyrektorami BPP (Leszek Talko, Kazimierz Piotr Lubicz-Zaleski), pełniąc nieodpłatnie powierzone funkcje zarządcze zgodnie ze statutami THL. Zob. K.P. LuBICZ-ZALESKI, Aneks, s. 15-16.

${ }^{28}$ L. Talko, Biblioteka Polska w Paryżu, rozmowę przeprowadziła A. Ciesielska-Ribard [14 stycznia 1999], „Roczniki. PAN. Stacja Naukowa w Paryżu” 2(2000), s. 161n. W rozmowie L. Talko zaznacza, że dom jest stary i przeciążony, przydałby się w obecnej chwili dodatkowy lokal magazynowy w Bibliotece do przechowywania zbiorów mniej cennych i dubletów. Pierwszy dyrektor BPP, Karol Sienkiewicz, proponował nabycie kamienicy na Polach Elizejskich. Uważano, że idealnym rozwiązaniem byłoby odzyskanie Hôtelu Lambert. Jednak odkupienie historycznej kamienicy księcia Adama wydawało się jednak wówczas niemożliwe. Zob. Leszek Talko (1916-2003): o Bibliotece Polskiej w Paryżu, rozmowę przeprowadził A. Gałkowski [z początku stycznia 2000], „Zeszyty Historyczne / Instytut Literacki” 2003, z. 146, s. 130, 132n.

${ }^{29}$ K.P. LuBicz-ZaLeSKi, Towarzystwo Historyczno-Literackie i Biblioteka Polska w Paryżu, 2004 i 2012, s. 11. 
decyzję, by podjąć na nowo, przerwane 10 lat wcześniej, rozmowy z PAU, w celu doprowadzenia do porozumienia i znalezienia rozwiązania ${ }^{30}$. W wyniku przeprowadzonych rozmów reprezentantów obu instytucji: prezesa i wiceprezesa THL z prezesem PAU, prof. Kazimierzem Kowalskim, i sekretarzem generalnym PAU, prof. Jerzym Wyrozumskim, zawarto porozumienie, które zostało zatwierdzone przez Radę PAU i Radę THL ${ }^{31}$. Obie zainteresowane strony podpisały umowę o utworzeniu Stowarzyszenia Biblioteki Polskiej w Paryżu (SBPP) / Association de la Bibliothèque Polonaise de Paris (ABBP) i po wypełnieniu procedury polubownego przeprowadzenia sprawy przez sąd w składzie: prof. Jean Foyer (prezes), prof. Bronisław Geremek, mec. Jean-Claude $\mathrm{Paye}^{32}$, oraz po otrzymaniu postanowienia sądu francuskiego rozpoczął się proces przekazania Biblioteki Polskiej nowo utworzonemu SBPP, które uzyskało prawo własności do budynku Biblioteki i jej zbiorów wraz z kolekcjami sztuki, a THL oraz PAU rezygnują z dotychczasowych praw na rzecz nowego Stowarzyszenia. Taki typ umowy gwarantował zachowanie jedności i całości mieszczących się w niej zbiorów oraz samego budynku. Jednocześnie umowa zobowiązała obie strony do wykazywania starań w celu pozyskiwania i przekazywania odpowiednich subwencji do dynamicznego funkcjonowania Biblioteki Polskiej w Paryżu oraz do tego, że zebrane zbiory i kolekcje pozostaną w dotychczasowym budynku BPP przy 6, Quai d'Orléans. Umowa SBPP przewiduje, aby obaj partnerzy byli reprezentowani w jednakowy sposób. Postanowiono, że PAU wynajmie budynek Biblioteki Polskiej THL, który pozostanie jego pełnoprawnym zarządcą do, co najmniej, $2030 \mathrm{r}$., a PAU udzieli mu odpowiedniego wsparcia w wypełnianiu jego zadań.

Mniejszościowa grupa członków THL niezadowolona z planów powstania umowy, wszczęła postępowanie prawne, aby do niej nie dopuścić. THL i PAU uzyskały wyrok sądu pierwszej instancji zatwierdzający ich układ, jak i w sądzie apelacyjnym. Większość wnioskodawców zaakceptowała ten wyrok i uregulowała zasądzone odszkodowania, jednakże dwie osoby wystąpiły w 2007 r. do sądu kasacyjnego, który w dn. 8 października orzekł o bezzasadności dochodzenia roszczenia i zasądził zapłatę odszkodowania ${ }^{33}$.

${ }^{30} \mathrm{O}$ planach i prowadzonych nieformalnych negocjacjach z PAU mających na celu znalezienie polubownego rozwiązania i jego zatwierdzenia przez Walne Zebranie członków THL wspominał Talko. Zob. Leszek Talko (1916-2003), s. 128n.

${ }^{31}$ W 2000 r. THL liczyło „ok. 400 członków różnych profesji, rozsianych po całym świecie. W większości są to ludzie czcigodni i zasłużeni, ale niekoniecznie na tyle zorientowani w specyfice zawodowej takiej instytucji, jak nasza Biblioteka, by decydować o sposobie jej prowadzenia. Nie ma wśród nich przedstawicieli z kraju i jest to sytuacja, którą w najbliższym czasie powinniśmy zmienić”. Zob. Leszek Talko (1916-2003), s. 133.

${ }^{32}$ K.P. LuBicZ-Zaleski, Towarzystwo Historyczno-Literackie i Biblioteka Polska w Paryżu, 2004 i 2012, s. 11. 
Sfinalizowanie prawa własności do budynku BPP i jej zbiorów wydawało się najlepszym zabezpieczeniem przyszłości Biblioteki Polskiej. Planowane prace modernizacyjne i remontowe miały spełniać cztery cele: 1) umocnić struktury nośne budynku (niektóre były osłabione i groziły zawaleniem), wymienić liczne belki stropowe po zawaleniu się sufitu; 2) wybudować magazyny pozwalające na właściwe przechowywanie zbiorów - pomieszczenia klimatyzowane z kontrolowaną regulacją temperatury i wilgotności powietrza, doposażone w filtry powietrza chroniące przed zanieczyszczeniami z zewnątrz (poddanie zbiorów odkażaniu i stopniowej konserwacji); 3) uzyskać dodatkową powierzchnię magazynową poprzez zainstalowanie regałów kompaktowych, pozwalających na właściwe i dogodne magazynowanie większej liczby dokumentów i książek w danym pomieszczeniu, co wymagało wzmocnienia podłóg, by mogły one unieść przewidywany ciężar $2 \mathrm{t} / \mathrm{m}^{2}$. Wzmocnienia podłóg dokonano we wszystkich pomieszczeniach piwnicznych, niektórych pomieszczeniach na parterze oraz na pierwszym piętrze. Działanie takie pozwoliło na przeniesienie zbiorów i wykorzystanie wolnych sal do innych celów; 4) wyposażyć budynek użyteczności publicznej w odpowiednie zabezpieczenia spełniające wymagane normy bezpieczeństwa i ochrony przed kradzieżą zbiorów, gdyż, niestety, takowe zdarzały się (nawet wśród pracowników) i trzeba było wszcząć procesy sądowe w celu ich odzyskania. Wymieniono wiele drzwi, całą instalację elektryczną według obowiązujących norm i sufity w licznych pomieszczeniach, by spełniały wymagania przeciwpożarowe ${ }^{34}$. Ponadto przeprowadzono jeszcze inne prace: odnowiono fasadę budynku od strony nabrzeża i dziedzińców - małego i dużego, wymieniono okna na analogiczne formą, ale chroniące przed nagrzaniem i hałasem od zewnątrz, zainstalowano windy dla osób z niepełnosprawnościami fizycznymi i dla pracowników przewożących zbiory. Salę konferencyjno-koncertową na parterze, tzw. Audytorium Jana Pawła II przebudowano tak, aby mogła pomieścić jednocześnie 100 osób, wyposażono w izofoniczne okna całkowicie izolujące od hałasów ulicznych i odpowiednią liczbę wyjść ewakuacyjnych. Naprzeciwko niej powstała druga, mniejsza sala konferencyjna dla 50 osób, połączona z pierwszą salą systemem audiowizualnym. $\mathrm{W}$ wielu pomieszczeniach zainstalowano klimatyzatory, zapewniające cyrkulację powietrza o dużym debicie wymiany $\left(2400 \mathrm{~m}^{3} / \mathrm{h}\right)$.

Decyzja o powołaniu SBPP okazała się korzystna dla THL, jak również pozwoliła głównym mecenasom zrealizować zamierzone plany: zapewnili finansowanie remontu i modernizacji BPP w $80 \%$ w latach $2000-2004$, która przez ten czas pozostawała nieczynna, a pracownicy w większości zwolnieni ${ }^{35}$. Do głównych ofia-

\footnotetext{
33 Tamże.

${ }^{34}$ Tamże, s. $11 \mathrm{n}$.

35 F.L. Ćwik, Biblioteka Polska w Paryżu: dziwne zwolnienia, „Nasz Dziennik” 2002, nr 10, s. 10.
} 
rodawców należeli: Fundacja im. Zygmunta Lubicz-Zaleskiego w Amsterdamie, którą założył Roman Zaleski (50\% potrzebnego budżetu), a także Stowarzyszenie Senatu RP Wspólnota Polska (około 30\%), Fundacja na rzecz Nauki Polskiej (która przekazała powyżej 2\% potrzebnej sumy). Pozostałe źródła funduszy pochodziły od dwóch instytucji francuskich: Rady Regionu l'Ile de France (około 8\%), Ministerstwa Kultury i Komunikacji (około 2,5\%). Wkład własny THL na rzecz remontu stanowiła kwota nieco ponad 5,5\% potrzebnej sumy pochodzącej z kilku ostatnio uzyskanych legatów ${ }^{36}$. Całkowity koszt remontu wyniósł około 4 mln euro ${ }^{37}$. Planując remont budynku, należało przewidzieć, że będzie on gruntowny, bowiem nigdy wcześniej nie był rzetelnie remontowany, oraz liczyć się z faktem, że pochodzący z 1655 r. budynek został włączony do rejestru zabytków i trzeba przestrzegać ścisłych wymogów narzucanych przez instytucję Bâtiments de France.

Historię dziejów BPP przedstawia pamiątkowa tablica umieszczona na dziedzińcu dużym Biblioteki pod orłem jagiellońskim z Wawelu, symbolizującym wolne państwo polskie. Po obu stronach tablicy upamiętniającej szczególne daty historyczne THL/BPP widnieją dwie tablice pamiątkowe z wykazem nazwisk osób najbardziej zasłużonych w powstaniu i działalności THL/BPP, które to tablice wmurowano w dn. 3 maja 1929 r. $^{38}$ Trwa żywa pamięć o zmarłych Polakach, członkach THL na francuskiej ziemi i co roku odbywa się pielgrzymka do Montmorency $\mathrm{z}$ nawiedzaniem grobów Polaków na starym cmentarzu Les Champeaux ${ }^{39}$.

Zmierzając w kierunku opuszczenia nieruchomości, na wysokości dziedzińca małego, na ścianie po prawej stronie umieszczono ostatnią tablicę upamiętniającą wkład instytucji polskich i francuskich w remont i modernizację budynku w latach $2000-2004^{40}$.

${ }^{36}$ K.P. LuBicz-ZALeski, Towarzystwo Historyczno-Literackie i Biblioteka Polska $w$ Paryżu, 2004 i 2012, s. 12.

37 K.P. ZALesKi, Towarzystwo Historyczno-Literackie i Biblioteka Polska w Paryżu, s. 32 (dokument elektroniczny).

${ }^{38}$ Zob. fotografie pamiątkowych tablic z nazwiskami osób zasłużonych dla BPP przedstawiono na wyklejkach publikacji: Towarzystwo Historyczno-Literackie, Biblioteka Polska w Paryżu: zarys historii i prezentacja zbiorów, Paryż-Warszawa 2014.

${ }^{39}$ W 2018 r. miała miejsce „175 pielgrzymka Polaków do Montmorency zorganizowana przez Towarzystwo Historyczno-Literackie przy współudziale Polskiej Misji Katolickiej we Francji, Kolegiaty św. Marcina w Montmorency, Ośrodka Dialogu Księży Pallotynów, Towarzystwa Opieki nad Polskimi Zabytkami i Grobami Historycznymi we Francji oraz Stowarzyszenia Polskich Kombatantów i ich Rodzin we Francji” w niedzielę dn. 10 czerwca 2018 r., http://www.bibliotheque-polonaise-paris-shlp.fr/index.php?id_page=21225 [dostęp: 2.11.2018].

${ }^{40}$ M. RaPaCKI, Otwarto Bibliotekę Polska w Paryżu, Gazeta.pl/Wiadomości, 28.09.2004, http:// wiadomosci.gazeta.pl/wiadomosci/1,114873,2310365.html [dostęp: 29.10.2009]; por. relację z przebiegu otwarcia Biblioteki Polskiej po zakończonym remoncie. „Pod koniec września udostępniona 


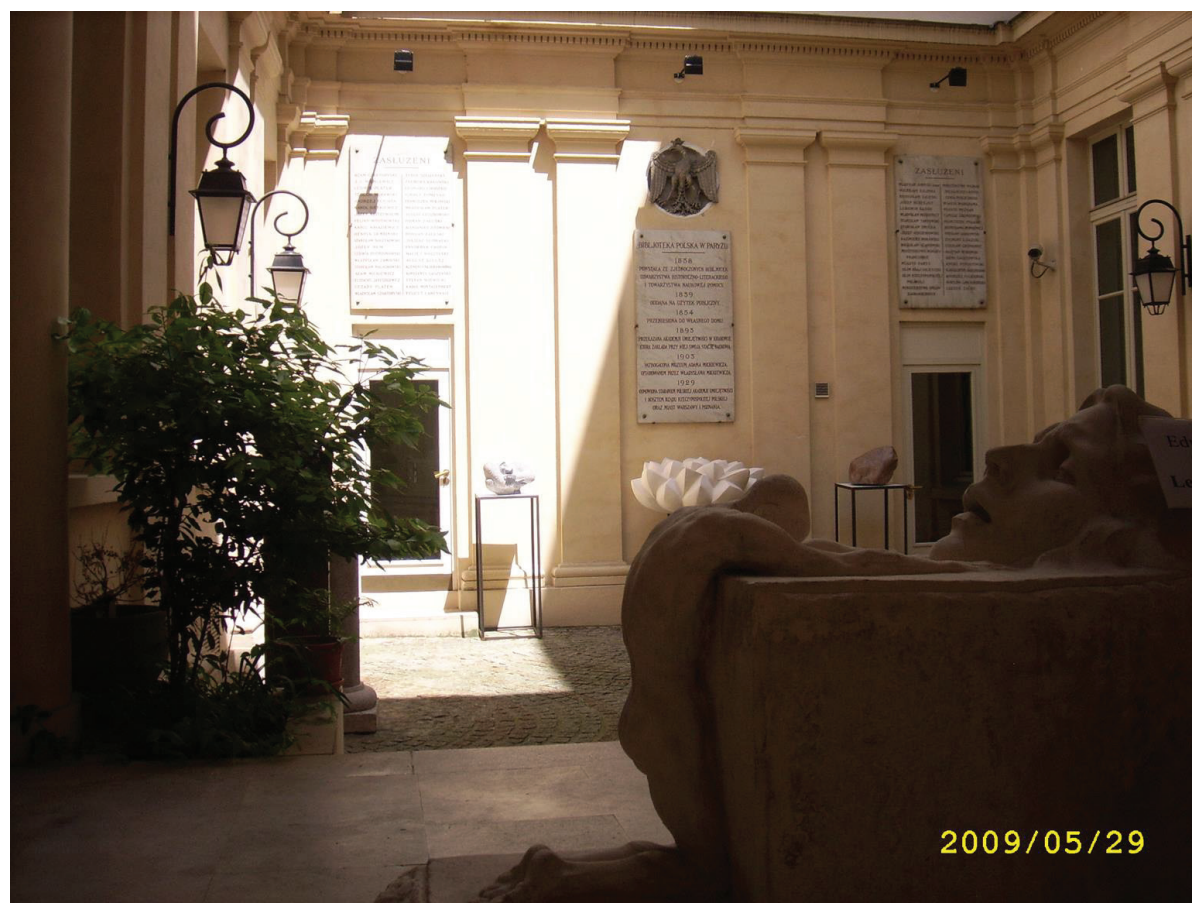

Widok na dziedziniec duży BPP od strony wejścia do budynku.

W tle rzeźby w kamieniu w trakcie wystawy „Sculptures et pastels de Beata Czapska” w dn. 30 marca - 10 kwietnia 2009 r. Fot. J. Okarma

Z perspektywy zawiłych i trudnych, ale interesujących losów THL/BPP, Rada THL wybrana w 1999 r. podjęła decyzję o utrzymaniu Biblioteki Polskiej jako instytucji prywatnej, korzystającej ze wsparcia, lecz nie większościowego, rządu polskiego oraz władz francuskich. Jak zaznacza prezes THL, prof. K.P. Lubicz-Zaleski:

[...] jest to rozwiązanie najbardziej dynamiczne, najbardziej obiecujące, pozwalające na istnienie ośrodka niezależnego od wszelkiej władzy politycznej, nawet jeśli jego działalność jest wspierana przez poszczególne rządy. To rozwiązanie jest korzystne dla ciągłości prac badawczych, wolności myśli, różnorodności postaw intelektualnych. Uwzględnia ono również specyfikę Biblioteki Polskiej i Towarzystwa Historyczno-Literackiego, podobnie zresztą jak nowego Stowarzyszenia Biblioteki Polskiej w Paryżu, utworzonego na podstawie umowy z Polską Akademią Umiejętności ${ }^{41}$.

została czytelnikom”. A. SiomKAJŁo, Największa na Zachodzie - Biblioteka Polska w Paryżu, „Studia Polonijne" 26(2005), s. 215.

${ }^{41}$ K.P. Lubicz-Zaleski, Towarzystwo Historyczno-Literackie i Biblioteka Polska w Paryżu, 2004 i 2012, s. 12. 
Dzięki umowie THL z PAU, od 2004 r. Akademia otrzymuje stałe subwencje od rządu polskiego na utrzymanie i funkcjonowanie Biblioteki Polskiej ${ }^{42}$. Te subwencje uzupełniały dotacje pozyskiwane ze źródeł prywatnych, pochodzących w głównej mierze od Fundacji im. Zygmunta Lubicz-Zaleskiego, i sprawiały, że sytuacja materialna Biblioteki Polskiej była dobra do czasu pojawienia się światowego kryzysu finansowego w 2008 r., od kiedy donator ograniczył beneficjentowi wsparcie. Do 2008 r. PAU pozyskiwało subwencje rządu polskiego na zatrudnienie i oddelegowanie specjalistów do pracy w THL/BPP ${ }^{43}$. Od 2009 r. fundusze celowe pozyskiwane przez PAU na rzecz Biblioteki Polskiej od rządu polskiego przeznaczane są na jej bieżące utrzymanie.

Odremontowany i zmodernizowany budynek, dzięki czterem dużym salom pozwala na rozwinięcie prowadzonej różnorodnej działalności naukowej i kulturalnej THL oprócz dotychczasowej: konserwacji, eksponowania zbiorów i udostępniania ich zainteresowanym (czytelnia, pracownia naukowa, muzea).

W 2004 r. powołano Komisję Naukową, zróżnicowaną pod względem jej członków, która wyznacza kierunki działalności naukowej i kulturalnej THL. W momencie powstania w jej skład weszli: prof. Maurice Aymard, prof. Maria Delaperrière (sekretarz generalna THL), Hélène Carrère d'Encausse - współprezes Komisji, prof. Bronisław Geremek - współprezes Komisji, Jean-Bernard Raimond - były

42 „W 1939 r. Sejm Rzeczypospolitej uchwalił, że do budżetu państwa, który będzie realizowany z rokiem budżetowym od 1 marca 1940 r., będzie stała dotacja dla Biblioteki Polskiej w Paryżu. Ta dotacja nie została zrealizowana. Można do tego wrócić”. J. PezDA, Uniwersytet Jagielloński, Biblioteka Książąt Czartoryskich, Dyskusja, [w:] Biblioteka Polska w Paryżu - skarbnica kultury narodowej: materiaty z konferencji zorganizowanej przez Komisję Spraw Emigracji i Łaczności z Polakami za Granica, 4 listopada 2014, Warszawa 2014, s. 60n (dokument elektroniczny), (fragment).

43 „Biblioteka w pewnym sensie stoi [...] na dwóch nogach, mianowicie jest Towarzystwo Historyczno-Literackie, które tam w Paryżu działa i bez niego oczywiście pewnie nic by się nie dało zrobić, ale jest również Polska Akademia Umiejętności w Krakowie, która jednak też działa, to znaczy te różne inicjatywy [...] [delegowanie pracowników do prac związanych z porządkowaniem, inwentaryzacją, opracowaniem zbiorów i utworzeniem katalogów zbiorów i in., por. tamże, s. 61n (dokument elektroniczny), (fragment)], te wszystkie granty idą przez Polską Akademię Umiejętności”. A. BiaŁas, Prezes Polskiej Akademii Umiejętności, Dyskusja, s. 62 (dokument elektroniczny), (fragment). W 2013 r. osoby związane z instytucjami kultury, bibliotek i archiwów polskich założyły Towarzystwo Przyjaciół BPP (TPBPP) w Warszawie, które obecnie liczy kilkunastu członków. Stowarzyszenie za cel stawia sobie wspieranie działań służących popularyzacji istnienia i zachowania polskiej spuścizny kulturowej przechowywanej w BPP, którą zarządza THL. „Jestem członkiem Zarządu Fundacji Zygmunta Zaleskiego z siedzibą w Amsterdamie i przedstawicielem na Polskę tej fundacji i również członkiem Towarzystwa Przyjaciół Biblioteki Polskiej w Paryżu, któremu przewodniczy pan dyrektor Biernat". T. JACKowski, Dyskusja, s. 63 (dokument elektroniczny), (fragment). Towarzystwo Przyjaciół Biblioteki Polskiej w Paryżu, http://www.przyjacielebpp.org/ [dostęp: 29.04.2018]. 
minister spraw zagranicznych Francji, prof. René Rémond, prof. Jerzy Wyrozum$\mathrm{ski}^{44}$, prof. Franciszek Ziejka, a także obecny prezes THL - prof. Kazimierz Piotr Lubicz-Zaleski. W 2008 r. z powodu śmierci prof. B. Geremka i prof. R. Rémonda do składu Komisji Naukowej dokooptowano prof. Jerzego Kłoczowskiego oraz prof. Michała Seweryńskiego - byłego ministra nauki i szkolnictwa wyższego. Na sekretarza Komisji powołano Witolda Zahorskiego. W 2012 r. dołączyli: prof. Marek Ziółkowski - były marszałek Senatu RP, prof. Jacques Legrand - prezes INALCO $^{45}$.

Tymczasem właściciel budynku Hôtel Lambert baron Guy de Rothschild w 2007 r. zapowiedział sprzedaż nieruchomości. Środowiska polonijne we Francji, jak i polscy parlamentarzyści zaczęli wytrwale zabiegać w polskim rządzie o odkupienie historycznego budynku w celu przeznaczenia go na ośrodek polski w Pary$\dot{z ̇ u}^{46}$. Wiadomo, że w lipcu 2007 r. Hôtel Lambert zakupił za kwotę $80 \mathrm{mln}$ euro brat emira Kataru - Hamad Ben Khalifa al-Thani ${ }^{47}$, który z pewnością nie jest z nim związany ani historycznie, ani patriotycznie, ani nawet nie wiążą go z budynkiem więzi sentymentalne. Niepokój społeczności lokalnej i konserwatorów zabytków wzbudził fakt powzięcia planu modernizacji i przebudowy historycznych zabudowań pałacowych z XVII wieku o powierzchni $3300 \mathrm{~m}^{2}$ i usunięcia jego oryginalnego wyposażenia wnętrz oraz wykończeń dekoratorskich przez nowego właściciela. Ostatecznie - po kilkumiesięcznej debacie publicznej - pośpieszne zapędy modernizacyjne udało się powstrzymaćc ${ }^{4}$. Nasuwa się w tym miejscu refleksja, być

${ }_{44}$ Odszedł 2 listopada 2018 r. Zob. B. KoŁodziej, M. Wosion-CzobA, Zmart prof. Jerzy Wyrozumski, wybitny historyk mediewista, https://dzieje.pl//aktualnosci/zmarl-prof-jerzy-wyrozumski-wybitny-historyk-mediewista [dostęp: 3.11.2018].

45 Zob. K.P. LuBICZ-ZALESKI, Towarzystwo Historyczno-Literackie i Biblioteka Polska w Paryżu, 2004 i 2012, s. 13.

${ }^{46}$ Por. L'hôtel Lambert : le grand voisin, „6, quai d'Orléans: lettre de la Société Historique et Littéraire Polonaise et de la Bibliothèque Polonaise de Paris" 2008, nr 11, s. 4-8, http://www.bibliotheque-polonaise-paris-shlp.fr/medias/biuletyn11.pdf [dostęp: 29.10.2009].

${ }^{47}$ F. Evin, Des Qataris un peu trop entreprenants. La famille de l'émir du Qatar a acheté en 2007 l'hôtel Lambert, sur l'île Saint-Louis, à Paris. Elle veut y faire réaliser de grands travaux : parking, ascenseurs... L'Etat, décisionnaire, y est favorable, „Le Monde” 20 décembre 2008, s. 3.

${ }^{48}$ F. Evin, M. Delanoë refuse la renovation de l'hôtel Lambert. Le projet de la famille de l'émir du Qatar attise les tensions entre la Ville et l'Etat, „Le Monde” 25 décembre 2008, s. 18; TENŻE, Hôtel Lambert : la polémique enfle entre M. Delanoë et M ${ }^{\text {me }}$ Albanel, „Le Monde” 26 décembre 2008, s. 15; TENŻE, Hôtel Lambert, suivez le guide, „Le Monde” 18-19 janvier 2009, s. 21; C. Mignot, Pour l'hôtel Lambert, faites encore un effort, Monsieur l'architecte en chef! Le plus discutable dans cette réhabilitation est le manque de bon sens patrimonial, „Le Monde” 24 février 2009, s. 17; F. Evin, Dernier round pour sauver l'hôtel Lambert, joyau de XVII', „Le Monde” 8-9 mars 2009, s. 18; F. Evin, Feu vert sous réserves à la réhabilitation de l'hôtel Lambert, „Le Monde” 12 mars 2009, s. 22. 
może przewrotna lub pochopna, ponownej utraty świadectwa historii i dziedzictwa polskiej kultury materialnej na emigracji pod nowymi rządami $\mathrm{RP}^{49}$.

W dalszej części omówimy kolejno poszczególne działy Biblioteki Polskiej i trzy muzea z ekspozycjami stałymi znajdującymi się na jej terenie.

\section{PRACOWNIA ZBIORÓW SPECJALNYCH THL/BPP: ARCHIWA I RĘKOPISY / SALLE DES CHERCHEURS}

Rękopisy Polaków na emigracji, archiwa osób prywatnych, polskich organizacji i instytucji, miscellanea i inne dary Biblioteka gromadziła z myślą o utworzeniu archiwum narodowego jako źródła nauki dla Polaków i cudzoziemców. Określenie „archiwum narodowe” (stosowane przez Karola Sienkiewicza, sekretarza księcia A.J. Czartoryskiego i pierwszego dyrektora Biblioteki Polskiej) miało wskazywać na gromadzone źródła do historii Polski i jej tysiącletniej chrześcijańskiej kultury, organicznie połączonej z Zachodem i cywilizacją europejską.

W archiwum pokolenie Wielkiej Emigracji zostawiło swoją młodość (np. papiery z powstania listopadowego) i swój wiek dojrzały (działalność uchodźczą). Pozostawiło dokumenty o zjawisku nowym, nieznanym na taką skalę, o swojej emigracji politycznej. Zostawiło znaki rozterek życia codziennego polskich wygnańców, tułaczej egzystencji, poglądów, sporów i politycznych spekulacji o rozpadzie i odrodzeniu duchowej wspólnoty, ślady formowania się nowych sposobów myślenia, mówienia i twórczości o doświadczeniach emigracyjnych i nadziejach o Polsce, jej przyszłości i miejscu w Europie ${ }^{50}$.

Na pierwszy apel odpowiedzieli patrioci Wielkiej Emigracji: poeci-Adam Mickiewicz, Juliusz Słowacki, Zygmunt Krasiński, Cyprian Kamil Norwid, Bogdan Zaleski, historycy - Joachim Lelewel, Teodor Morawski, Walerian Kniaziewicz,

${ }^{49}$ Budynek Hôtelu Lambert, „który odegrał tak ważną rolę w życiu Wielkiej Emigracji, ale który dzisiaj jest już budynkiem należącym do jednego z szejków Kataru, gdzie nie ma właściwie nawet wzmianki o tym, że to było miejsce dla Polaków tak bardzo ważne przez bardzo długie lata" [mowa tu o braku kamiennej tablicy pamiątkowej - przyp. J.O.]. F. ZIEJKA, Biblioteka Polska w Paryżu-skarbnica kultury narodowej, [w:] Biblioteka Polska w Paryżu - skarbnica kultury narodowej: materiaty, s. 36 (dokument elektroniczny). Por. głosy w dyskusji: E. SęCZYKowska, J. KozińsKa-FrYBes, J. MiLER, J. PezDa, Dyskusja, s. 55-56, 61 (dokument elektroniczny), (fragment). Niestety, w dn. 10 lipca 2013 r. w budynku Hôtel Lambert wybuchł pożar, który strawił znaczną część gmachu. Wobec zaistniałej sytuacji właściciel posiadłości uzyskał zgodę odnośnych władz lokalnych na przebudowę nieruchomości. Zob. F. ZIEJKA, Skarby kultury polskiej, s. 18.

${ }^{50}$ E. RutKowsKa, Wiatyk na wieczność. O archiwach rękopiśmiennych Biblioteki Polskiej w Paryżu, 2008 i 2011, [w:] Towarzystwo Historyczno-Literackie, Biblioteka Polska w Paryżu, s. 19. 
Józef Bem, Henryk Dembiński, Józef Dwernicki, prezes Rządu Narodowego książę Adam Czartoryski, uczeni i pisarze - Ignacy Domeyko, Maurycy Mochnacki, Julian Klaczko, Feliks Wrotnowski, księża zmartwychwstańcy - Tomasz Jełowicki, Piotr Semenenko, Hieronim Kajsiewicz, artyści - Antoni i Władysław Oleszczyńscy, Teofil Kwiatkowski, Henryk Rodakowski, muzycy - Fryderyk Chopin, Albert Sowiński. Te i inne osoby przekazywały najpierw swoje dary organizacjom: Towarzystwu Pomocy Naukowej i Towarzystwu Literackiemu Polskiemu. Pierwszy znaczniejszy dar pochodził od Gustawa Małachowskiego; potem doszły: Juliana Ursyna Niemcewicza, Karola Otto Kniaziewicza, Józefa Bema, S. Barzykowskiego. Przesyłano i ofiarowywano liczne rękopisy, druki od Senatora Macieja Wodzińskiego, księgozbiór płk. Szulca, akta Sejmu 1830-1831, archiwa wojskowe ze Sztabu Generalnego WP, Polskiej Misji Katolickiej 1830-1831, pamiątki uczestników powstania listopadowego, wojen napoleońskich i polskich organizacji emigracyjnych (np. Instytucji „Czci i Chleba” ${ }^{51}$, Zakładu Weteranów św. Kazimierza ${ }^{52}$, Towarzystwa Filharmonicznego Polskiego w Paryżu ${ }^{53}$, Towarzystwa Nauk Ścisłych $\mathrm{w}$ Paryż ${ }^{54}$ ), potem dochodziły także odpisy dokumentów z archiwów londyńskich i paryskich. Po połączeniu się organizacji TL i TH w 1854 r. składowano je w Bibliotece Polskiej w Paryżu.

Pierwszy dyrektor BPP Karol Sienkiewicz rozesłał swoich pracowników, aby w różnych francuskich i europejskich instytucjach, archiwach, bibliotekach, urzędach kopiowali wszelkie polonika. W taki sposób nazbierano przeróżne rękopisy polskie lub ich kopie: papiery rodzinne obejmujące 612 nazwisk Wielkiej Emigracji (94 968 stron), dokumenty zakupione, ofiarowane przez darczyńców i ich rodziny, zapisane $\mathrm{w}$ testamentach, spadkach, archiwa instytucji (Szkoła Polska na Batignolles, Szkoła Panien Polskich) i organizacji emigracyjnych (Towarzystwo Dobroczynności Dam Polskich) XIX-XX wieku, tworząc największe archiwum emigracyjne. Dotychczas w kolekcjach Salle des Chercheurs zgromadzono

${ }^{51}$ Instytucja „Czci i Chleba”. (Akt założenia, sprawozdania ...), Paryż 1862-1882, Zbiory BPP, sygn. 41140 (dep. BP w ML), [za:] Skarby kultury polskiej ze zbiorów Biblioteki Polskiej w Paryżu, Warszawa 2004, s. [25] (s.n.). Zob. J. Pezda, Suplement do tomu V Katalogu Rękopisów Biblioteki Polskiej w Paryżu. Stowarzyszenie podatkowe - Instytucja „Czci i Chleba”, sygn. 756759, [w:] Wspólna sprawa. Studia i materiały do dziejów emigracji polskiej we Francji, Kraków 2017, s. 119-133.

52 Początkowo założony przy rue $d u$ Chevaleret $\mathrm{w} 1846 \mathrm{r}$. jako sierociniec, a następnie funkcjonujący jako dom opieki nad polskimi weteranami aż do czasów obecnych; w nim ostatnie lata życia spędził m.in. Cyprian Kamil Norwid, za: F. ZIEJKA, Skarby kultury polskiej, s. 25.

${ }^{53}$ Ustawy Towarzystwa Filharmonicznego Polskiego w Paryżu, Paryż 1880, Zbiory BPP, sygn. 93407, (dep. BP w ML), [za:] Skarby kultury polskiej ze zbiorów Biblioteki Polskiej, s. [25].

${ }^{54}$ Pamiętnik Towarzystwa Nauk Ścistych w Paryżu, t. 10, Paryż 1878, Zbiory BPP, sygn. 001878 (dep. BP w ML), [za:] Skarby kultury polskiej ze zbiorów Biblioteki Polskiej, s. [25]. 
3 tys. rękopisów ${ }^{55}$. Do najcenniejszych dokumentów należą autografy królewskie z wieków XVI-XVIII, archiwa księcia Konstantego, Akta Polskiej Misji w Paryżu z 1830 r. i dotyczące powstań narodowych $(1794,1830-1831,1848,1863)$, a także akt detronizacji cara Mikołaja I z tronu polskiego z 200 oryginalnymi podpisami arystokracji polskiej, i inne.

Niektóre zgromadzone starodruki mają szczególną wartość: trzy kolejne wydania dzieła Mikołaja Kopernika De revolutionibus orbium coelestium (Norymberga 1543; Bazylea 1566; Amsterdam 1617), jedno z pierwszych wydań dzieł Marcina Lutra, rzadkie wydanie Biblii Jakuba Wujka, dzieła ks. Piotra Skargi, zbiory kazań z XVII wieku, pisma twórców reformacji i kontrreformacji w Polsce i Europie Środkowej.

Na uwagę zasługuje - do tej pory prawie niezauważony - zbiór opraw książkowych od XV wieku do czasów współczesnych. Dominują wśród nich dzieła zachodnioeuropejskie, zwłaszcza francuskie, z bogatą paletą stylów i indywidualnych wzorów w zakresie dekoracji okładzin, grzbietów, obcięć kart czy wyklejek. XVI-wieczne oprawy wykonane w Polsce wyróżniają się charakterystyczną formą i ikonografią dekoracji. Uwagę zwracają prace polskich introligatorów w Paryżu z XIX i XX wieku. Znaczna część zabytkowych opraw posiada superekslibrisy i ekslibrisy stanowiące pamiątkowe znaki własnościowe po dawnych właścicielach bibliotek prywatnych i instytucjonalnych, jak też wyklejki dawnej heraldyki europejskiej ${ }^{56}$.

Zbiory archiwalne XX wieku powiększyły się o papiery po dyrektorach, kustoszach i przyjaciołach BPP ${ }^{57}$. W latach 1972-1974 po sprzedaży Hôtelu Lambert przekazano do Biblioteki część archiwum domowego książąt Czartoryskich; w 2012 r. - archiwum Stowarzyszenia Solidarité France-Pologne / Association Solidarité France-Pologne za lata od jesieni 1980 do 2004, działającego poprzez 200 komitetów we Francji i nadal aktywnego, ale już w innym zakresie ${ }^{58}$.

${ }^{55}$ E. RutKowska, Wiatyk na wieczność. O zbiorach rękopiśmiennych Biblioteki Polskiej w Pary$\dot{z} u$, http://www.bibliotheque-polonaise-paris-shlp.fr/medias/TEKSTERPL.pdf [dostęp: 29.10.2009]. Zob. wybór z listy dokumentów i ofiarodawców. TAż, Wiatyk na wieczność. O archiwach rękopiśmiennych Biblioteki Polskiej w Paryżu, 2008 i 2011, s. 19-20.

${ }^{56}$ Więcej: A. WAGNER, By chronić i zdobić: o oprawach, superekslibrisach i ekslibrisach w Bibliotece Polskiej w Paryżu, Paryż-Toruń 2014, s. 8n; TENżE, Najpiękniejsze superekslibrisy i ekslibrisy XVI-XX wieku w zbiorach Biblioteki Polskiej w Paryżu, „Tekstualia” 2013, nr 3, s. 191-200.

${ }^{57}$ Więcej: E. RutKowsKa, Wiatyk na wieczność. O archiwach rękopiśmiennych Biblioteki Polskiej w Paryżu, 2008 i 2011, s. 20.

58 Więcej: M. Heruday-KieŁczewsKa, Archiwum Stowarzyszenia Solidarité France-Pologne w zbiorach Biblioteki Polskiej w Paryżu, „Folia Toruniensia” 2017, nr 17, s. 175-187; Inventaire des Archives de l'Association Solidarité France-Pologne 1980-2004. Inwentarz Archiwum Stowarzyszenia Solidarité France-Pologne 1980-2004, oprac. M. Heruday-Kiełczewska, Paris 2013. 
Wśród zróżnicowanych zbiorów rękopiśmiennych na uwagę zasługują muzykalia, głównie z XIX i XX wieku, np. dziewiętnastowieczne utwory sztambuchowe i samodzielne kompozycje z paryskiego Muzeum Adama Mickiewicza, dwudziestowieczne zbiory muzyczne zawierające autografy, kopie rękopiśmienne, druki (część z nich z dedykacjami). Wśród muzykaliów znajdują się m.in. autografy: Jana Sebastiana Bacha, Fryderyka Chopina, Zygmunta Dygata, Stanisława Moniuszki, Michała Spisaka ${ }^{59}$, Marii Szymanowskiej, Władysława Żeleńskiego ${ }^{60}$.

Zgromadzone licznie archiwa i rękopisy prywatne w postaci korespondencji i dokumentów z archiwów urzędowych oraz spuścizny znanych polskich pisarzy i poetów XIX i XX wieku mieszkających we Francji oraz cenne po nich pamiątki przyciągają naukowców i badaczy z Polski i innych krajów, nie tylko europejskich, prowadzących badania zwłaszcza nad historią i kulturą polskiej emigracji XIX-XX-wiecznej.

Dotychczas opracowano 8 drukowanych katalogów rękopisów, z podziałem na jednostki archiwalne oznaczone sygnaturami ${ }^{61}$.

${ }^{59}$ Więcej: R. Suchowiejкo, Spuścizna Michała Spisaka (1914-1965) w Paryżu: nowe źródta do badań nad twórczościa kompozytora, „Muzyka” 2015, nr 2, s. 55-62, Aneks: wykaz utworów M. Spisaka, s. 63-97.

${ }^{60}$ E. RutKowsKa, Wiatyk na wieczność. O archiwach rękopiśmiennych Biblioteki Polskiej w Paryżu, 2008 i 2011, s. 20.

${ }^{61}$ Dwa najstarsze katalogi, wydane przez PAU, ukazały się przed II wojną światową: pierwszy obejmował rękopisy Adama Mickiewicza: Katalog rękopisów Muzeum Adama Mickiewicza, oprac. A. Lewak, wstęp F. Pułaski, Kraków 1931; drugi obejmował materiały luźne i miscellanea: Katalog rękopisów Biblioteki Polskiej w Paryżu, t. 1, sygn. 1-43, oprac. Cz. Chowaniec, Kraków 1939; katalog powojenny dotyczył zawartości archiwum Instytucji „Czci i Chleba”: Katalog rękopisów Biblioteki Polskiej w Paryżu, t. 5, sygn. 664-755, oprac. J. Skarbek, J. Ziółek, wstęp J. Mond, Lublin-Paryż 1990. Prace nad porządkowaniem dokumentów i różnych archiwów, a następnie sporządzeniem inwentarza akcesyjnego archiwów rękopiśmiennych dokonali w latach 1992-1994 dwaj pracownicy z Zakładu Rękopisów Biblioteki Narodowej: Andrzej Kłossowski i Łukasz Kądziela, oraz Biblioteki Czartoryskich w Krakowie, we współpracy z Andrzejem Folkierskim z THL, a po jego śmierci - Leszkiem Talko. Inwentarz ukazał się drukiem, w 4 tomach obejmował około 5 tys. opisów, t. 5 zawierał indeksy nazw osób, instytucji i organizacji, proweniencję, chronologię, wykaz sygnatur dawnych i nowych. Biblioteka Narodowa w Warszawie i Biblioteka Czartoryskich w Krakowie współwydały katalog listów, notat, autografów, papiery polskiej emigracji XIX wieku: Katalog rękopisów Biblioteki Polskiej w Paryżu, t. 2, sygn. 432-545, oprac. Cz. Chowaniec, I. Gałęzowska, uzup. i przygotował do druku M.P. Prokop, Paryż-Warszawa 1994. Ostatni wymieniony tom ukazał się wcześniej pt. Inwentarz rękopisów Biblioteki Polskiej w Paryżu, oprac. Cz. Chowaniec, I. Gałęzowska, Paryż 1986. Tom zawierający archiwa Hotelu Lambert: Katalog rękopisów Biblioteki Polskiej w Paryżu, t. 6, sygn. 760-1135, oprac. J. Pezda, Paryż-Warszawa 1996, oraz katalog ze spuściznami XX wieku, obejmujący archiwa Konstantego Brandla, Jana Brzękowskiego, Aleksandra Kawałkowskiego, Stanisława Lama i Ludwika Lillego: Katalog rękopisów Biblioteki Polskiej w Paryżu, t. 7 , sygn. 1136-1359, oprac. M. Gamdzyk-Kluźniak, D. Kamolowa, A. Kaszlej, M.P. Prokop, T. Sienia- 
Dzięki dotacji Ministerstwa Kultury i Dziedzictwa Narodowego w 2007 r. w pracowniach konserwatorskich Archiwum Akt Dawnych przeprowadzono konserwację archiwum Izby Obrachunkowej Rządu Tymczasowego z lat 60. XIX wieku. Specjaliści z AAD uzupełnili i dokończyli inwentarz zespołu oraz zdigitalizowali całośćc6. W Bibliotece Narodowej odrestaurowano najbardziej zagrożone archiwa Franciszka Krahnasa ${ }^{63}$. Należy dodać, że od 2006 r. Institut national de patrimoine w Paryżu konserwuje bezpłatnie pergaminy z kolekcji rękopiśmiennej BPP ${ }^{64}$.

Pracownia Zbiorów Specjalnych / Salle des Chercheurs przeznaczona jest do pracy dla naukowców, badaczy. Po uzyskaniu autoryzacji osoby odpowiedzialnej i dyrektora BPP mogą korzystać z archiwów i rękopisów. Czytelnicy mają do dyspozycji opisy katalogowe 1114 sygn. z kolekcji Muzeum Adama Mickiewicza i 1881 sygn. Biblioteki Polskiej w Paryżu ${ }^{65}$.

\section{MUZEUM MICKIEWICZA / MUSÉE DE MICKIEWICZ}

Pełniący funkcję dyrektora BPP - delegat PAU i zarazem sekretarz Komitetu Miejscowego Stacji Naukowej Akademii Umiejętności Władysław Mickiewicz, w 1901 r. wraz z tym Komitetem wystosował pismo do Wysokiej Akademii Umiejętności w Krakowie o jego zamiarze założenia przy Bibliotece Muzeum Adama Mickiewicza. Propozycja została przyjęta, a Muzeum otwarto w 1903 r. Muzeum Mickiewicza / Musée de Mickiewicz to wyjątkowy zasób rękopisów, książek,

tecka, Paryż-Warszawa 1996. Nakładem PAU opublikowano katalog obejmujący dokumenty towarzystw emigracyjnych oraz inne archiwalia z lat 1832-1893: Katalog rękopisów Biblioteki Polskiej w Paryżu, t. 8, sygn. 1360-1705: archiwum administracyjne Towarzystwa Literackiego, Wydziału Statystycznego, Wydziału Historycznego, Towarzystwa Historycznego, Towarzystwa Historyczno-Literackiego i Biblioteki Polskiej z lat 1832-1893, oprac. J. Pezda, M.P. Prokop, Paryż-Kraków 2006. Ponadto z inicjatywy Biblioteki Narodowej ukazał się Przewodnik po zespołach rękopisów Towarzystwa Historyczno-Literackiego i Biblioteki Polskiej w Paryżu, oprac. M. Wrede, M.P. Prokop, J. Pezda, Paryż-Warszawa 2000; Katalog rękopisów Biblioteki Polskiej w Paryżu, t. 11: rękopisy nr 2064-2556, rękopisy XIX-wieczne, oprac. M. Jaglarz, U. Klatka, J.S. Nowak, J. Pezda, przy współpracy M. Junkiewicz, Paryż-Kraków 2017. Zob. E. Rutkowska, Wiatyk na wieczność. O archiwach rękopiśmiennych Biblioteki Polskiej w Paryżu, 2008 i 2011, s. 21.

${ }^{62}$ E. RutKowska, Wiatyk na wieczność. O archiwach rękopiśmiennych Biblioteki Polskiej w Paryżu, 2008 i 2011, s. 21.

${ }_{63}$ Sprawozdanie Biblioteki Narodowej za rok 2008, Warszawa 2009, s. 134n, http://www.bn.org. $\mathrm{pl} /$ download/document/1241790645.pdf [dostęp: 09.12.2009].

${ }^{64}$ E. RutKowsKa, Wiatyk na wieczność. O archiwach rękopiśmiennych Biblioteki Polskiej w Paryżu, 2008 i 2011, s. 21.

${ }^{65}$ Tamże. 
obrazów i przedmiotów osobistych po Adamie Mickiewiczu, licznych portretów w formie rycin, litografii, rzeźb (np. studium Mickiewicza przedstawiające go jako pielgrzyma polskiego, autorstwa Emile'a Antoine'a Bourdelle'a; pomnik naturalnych rozmiarów stanął w 1929 r. na Place Alma w Paryżu, tuż przy Sekwanie) czy medali (wiele jest autorstwa Władysława Oleszczyńskiego lub francuskiego rzeźbiarza Davida d'Angersa, autora popiersia poety z 1835 r., których złączyła trwała przyjaźń), książek i przedmiotów osobistych ofiarowanych przez najstarszego syna ${ }^{66}$.

Pierwsze prace nad inwentarzem autografów Adama Mickiewicz prowadzili jego przyjaciele w 1856 r., potem każdy rękopis odnotowywał jego syn Władysław. Następnie zajął się tym Adam Lewak, sporządzając katalog. W 1931 r. wespół z PAU wydano Katalog rękopisów Muzeum Adama Mickiewicza w Paryżu, który obejmował 1113 sygnatur uporządkowanych według kolejności: pisma i rozmowy Adama Mickiewicza, utwory literackie, wykłady lozańskie, wykłady w Collège de France, pisma i przemówienia w sprawie Andrzeja Towiańskiego, noty w sprawie Legionów Polskich we Włoszech, La Tribune des Peuples zawierające korespondencję poety z różnymi osobami.

Kolekcja rękopisów ciągle się powiększała, najpierw dzięki pierwszemu spadkobiercy pamiątek po ojcu i niezwykłemu oddaniu powierzonej misji - Władysławowi Mickiewiczowi, a potem jego następcom. I tak Biblioteka w 1934 r. zakupiła list Adama Mickiewicza do Antoniego Edwarda Odyńca z lutego 1825 r. Na przełomie roku 1938/1939 zakupiono afisz informacyjny o wykładach poety w Collège de France w 1844 r.

Zasób rękopisów i archiwów po Adamie Mickiewiczu uporządkowano, podzielono na jednostki archiwalne, oznaczono sygnaturami opatrzonymi w BPP, opracowano i opublikowano w dwu katalogach. Pierwszy to Katalog rękopisów muzeum Adama Mickiewicza, oprac. A. Lewak, wstęp F. Pułaskiego, Kraków 1931, wydany przez PAU. Drugi ujmował materiały luźne i miscellanea - Katalog rękopisów Biblioteki Polskiej w Paryżu, t. 1, nr sygn. 1-431, oprac. Cz. Chowaniec, Kraków 1939, index oprac. J. Pezda, Paryż 1995.

Po ponad 150. latach od śmierci poety nadal odnajdują się jeszcze oryginały listów, bądź nieznanych, bądź publikowanych na podstawie kopii: odpisów lub reprodukcji zgromadzonych w Bibliotece Polskiej. W taki sposób Ewa Rutkowska dotarła do oryginału listu poety znajdującego się w Archives nationales we Francji z 10 lutego 1843 r. do Charles'a Duchâtela, ministra spraw wewnętrznych Francji,

\footnotetext{
${ }^{66}$ Fotografie prezentujące wszystkie trzy mieszczące się w budynku BPP muzea dostępne są na stronie internetowej THL/BPP, http://www.bibliotheque-polonaise-paris-shlp.fr/index.php?id_rubrique $=1139$ [dostęp: 29.04.2018].
} 
w sprawie naturalizacji nadawcy i oryginału listu do księcia Napoleona Bonaparte z 11 stycznia z $1852 \mathrm{r}^{67}$

Biblioteka Narodowa we współpracy z Ministerstwem Kultury i Sztuki zmikrofilmowała 950 jednostek archiwalnych z kolekcji Muzeum Adama Mickiewicza w BPP. Dzięki umowie o współpracy z PAU z 2005 r. sporządzono szczegółowe opracowania spuścizn artystów polskich, kilku dyplomatów, archiwum Ambasady Polskiej w Paryżu, Konsulatu Polskiego w Tuluzie, część materiałów po Polskim Czerwonym Krzyżu i Towarzystwie Opieki nad Polakami we Francji. Rozpoczęto opracowanie obszernej spuścizny zespołu rękopiśmiennego Kazimierza Woźnickiego. W 2004 r. cenne rękopisy z Muzeum Adama Mickiewicza i Biblioteki Polskiej upubliczniono podczas wystawy „Skarby kultury polskiej ze zbiorów Biblioteki Polskiej w Paryżu" zorganizowanej w Warszawie i Krakowie. Wcześniej poddano je gruntowej konserwacji w Zakładzie Konserwacji Zbiorów Bibliotecznych BN w Warszawie.

W tym miejscu można zaznaczyć, że od 1955 r. w Muzeum Literatury im. Adama Mickiewicza w Warszawie (uprzednio Muzeum Adama Mickiewicza) znajduje się tzw. depozyt paryski, którego część rękopiśmienna obejmuje zbiory paryskiego muzeum. Na mocy umowy zawartej między Muzeum Literatury im. Adama Mickiewicza w Warszawie a THL/BPP z 2 sierpnia 2009 r. depozyt rękopisów i książek został złożony w Warszawie na dziesięć lat, tj. do 31 lipca 2019 r. z możliwością przedłużenia terminu. Z pozostających zaś w depozycie ponad 12 tys. kart z paryskiego muzeum poety i Biblioteki Polskiej część depozytu rękopiśmiennego - 1400 k.: papierów dotyczących Księgarni Luksemburskiej, dokumentów i korespondencji sekretarza A. Mickiewicza, Armanda Lévy'ego, papierów Denisa Zaleskiego, prezesa Instytucji „Czci i Chleba”, oraz Andrzeja Teslara - powróciła do Paryża ${ }^{68}$.

\section{SALON FRYDERYKA CHOPINA / SALON CHOPIN}

Choć kompozytor spędził w Paryżu większą część swojego życia (tj. 18 lat) i często się przeprowadzał w obszarze miasta (jego pobyt zaznaczają trzy pamiątkowe tablice kamienne), nie doczekał się w tym mieście prawdziwego muzeum upamiętniającego jego życie i twórczość. Salon Fryderyka Chopina - Salon Chopin w gmachu Biblioteki Polskiej utworzono tuż po II wojnie światowej. Wypo-

${ }^{67}$ E. RutKowsKa, Wiatyk na wieczność. O archiwach rękopiśmiennych Biblioteki Polskiej w Paryżu, 2008 i 2011, s. 20.

${ }^{68}$ Tamże, s. 22. 
sażono go w eksponaty wyselekcjonowane z kolekcji Muzeum Adama Mickiewicza i zgromadzone przez THL chopiniana. Chopin był członkiem THL od $1833 \mathrm{r}$. W salonie wystawiono jego liczne fotografie i portrety ${ }^{69}$, ryciny, miniatury, portrety osób zaprzyjaźnionych, medaliony stworzone przez Władysława Oleszczyńskiego, przedstawiające wizerunki polskich emigrantów - przyjaciół Chopina: Juliana Fontany, Stefana Witwickiego, autografy i dedykacje pisane na partyturach dla uczennic, pukiel włosów, maskę pośmiertną i odlew lewej dłoni wykonane przez męża Solange - córki George Sand - Augusta Clésingera, a także zakupiony na aukcji przez zaprzyjaźnionego z nim malarza Teofila Kwiatkowskiego (18091891) fotel kompozytora $\mathrm{z}$ jego ostatniego mieszkania przy 12, Place Vendôme ${ }^{70}$. Teofil Kwiatkowski jest autorem wielu akwareli i rysunków podobizny Chopina, a także znanego pod dwoma tytułami obrazu „Polonez Chopina” lub „Bal w Hôtelu Lambert”. Do kolekcji udało się sprowadzić zabytkowy fortepian marki „Player" z 1845 r.

\section{PRACOWNIA KOLEKCJI ARTYSTYCZNYCH / COLLECTION ARTISTIQUE}

Polscy emigranci i Francuzi polonofile oddawali różne pamiątki narodowe, nie tylko archiwalia i książki. Czasami zdarzały się pamiątki osobiste, zbierane przez lata, odkładane kolekcje i spuścizny osobiste, dary i zapisy. W taki sposób trafiały się rzeczy czysto przypadkowe, co ani nie były dokumentem pisanym, ani książką. $\mathrm{Z}$ nich utworzono oddzielny zbiór pamiątek dotyczących życia codziennego i kulturalnego Polaków we Francji.

Zgromadzone w THL/BPP kolekcje artystyczne powierzono opiece pracownikom Pracowni Kolekcji Artystycznych / Collection Artistique $e^{71}$. Ze względu na prowadzone i kontynuowane prace inwentaryzacyjne zachowano tradycyjny podział eksponatów: malarstwo, rysunek, grafika (którymi zajmuje się Gabinet Rycin

${ }^{69}$ M.M. GrąBCzewska, Powstanie i historia dagerotypowych wizerunków Fryderyka Chopina - nowe ustalenia, „Muzyka” 2008, nr 3, s. 75-86.

${ }^{70}$ Aranżacja Salonu Chopina (pow. $22 \mathrm{~m}^{2}$ ) przeprowadzona w 2010 r. nawiązuje wyglądem do salonu Chopina w mieszkaniu przy Place Vendôme $12 \mathrm{z}$ akwareli na papierze Teofila Kwiatkowskiego z 1849 r. Zob. A. NiewĘGlowski, Salon Chopina, „Cenne, Bezcenne / Utracone” 2011, nr 2, s. 14-15; P. IGnACZAK, Muzea w Bibliotece Polskiej w Paryżu, „Muzealnictwo” 2016, nr 57, s. 230.

${ }^{71}$ Zob. A. CZARnocka, Kolekcje artystyczne Biblioteki Polskiej w Paryżu, http://www.bibliotheque-polonaise-paris-shlp.fr/medias/TEKSTACPL.pdf [dostęp: 29.10.2009]. Szczodrych ofiarodawców wymienia: A. Czarnocka, Kolekcje artystyczne Biblioteki Polskiej w Paryżu, 2012, [w:] Towarzystwo Historyczno-Literackie, Biblioteka Polska w Paryżu, s. 174-177. 
i Rysunków), fotografia, rzeźba i numizmatyka (nad którymi pracuje Gabinet Monet i Medali) oraz rzemiosło artystyczne.

W zbiorach THL/BPP zgromadzono: około 25 tys. rysunków i rycin ${ }^{72}$, kolekcje kartograficzne pieczołowicie zbierane przez Czesława Chowańca, liczące dziś ponad 6200 obiektów, w tym 4250 tytułów map (czasami jedna mapa w kilku arkuszach) i atlasów od XVI wieku: plany bitew, plany miast, 1420 obrazów, 350 rzeźb, około 1 tys. afiszy, 90 tys. druków ulotnych, około 5 tys. starych fotografii, dagerotypów ${ }^{73}$, klisz, negatywów, 600 medali i monet.

Poza wymienionymi pamiątkami znajdują się meble sławnych Polaków, m.in. fotel księcia Adama Czartoryskiego z pobliskiego Hotelu Lambert, biurko Adama Mickiewicza, przy którym pisał Pana Tadeusza (obecnie stanowi eksponat w Muzeum Mickiewicza w THL/BPP), biurko i fotel Karola Sienkiewicza, przy którym później pracował dyrektor BPP Władysław Mickiewicz. Zachowało się także biurko, krzesło i szafa Marii Skłodowskiej-Curie, która pełniła funkcję wiceprzewodniczącej Komitetu Miejscowego Biblioteki Polskiej.

Kontynuowane prace nad sporządzeniem inwentarza portretów, podobizny i pamiątek po Adamie Mickiewiczu praktycznie zakończyły w 1948 r. Bronisława Mońkiewicz i Emilia Fiszer. Później uzupełniono go o nowe obiekty pochodzące z darów i nabytków po II wojnie, otrzymując 668 pozycji. W efekcie przeprowadzonych prac, w 1955 r. wydano studium ikonograficzne 35 prac Portrety Adama Mickiewicza w Muzeum Adama Mickiewicza w Paryżu autorstwa Eugenii Żarnowskiej.

Do 1989 r. kolekcje BPP wzbogaciły się o darowizny i legaty, w szczególności o spuściznę Kamila Gronkowskiego, byłego prezesa THL, oraz legaty i darowizny

72 Pierwszą inwentaryzację i klasyfikację najliczniejszego zbioru graficznego przeprowadził Erazm Mułkowski w 1865 r. Ponownie opracowano wzbogacony dział rycin w latach 1927-1931, sporządzono katalog kartkowy według nazw osobowych rytowników, malarzy i haseł tematycznych. Bogatą kolekcję dzieł obcych malarzy przekazał Maciej Wodziński, a opracował dr Jerzy Sienkiewicz w latach 1931-1932 i utworzył katalog kartkowy według haseł. W latach 1948-1949 opublikowano katalogi rycin przygotowane przez E. Fiszer, D. Wrotnowską: t. 1, 2; kolejne trzy katalogi rycin: t. 3, 4, 5 w układzie według rytowników w 1950 r. D. Wrotnowska opublikowała ponadto Stownik artystów polskich emigracji 1830 roku: malarzy, grafików, litografów i rytowników. Prace nad kolekcją malarstwa (liczącego ponad 1420 dzieł) oraz rysunków (około 2400) prowadzili X. Deryng, a potem E. Bobrowska-Jakubowska w latach 70. XX wieku. Prace są kontynuowane, podobnie jak nad katalogiem rzeźby czy rzemiosła artystycznego. Zob. A. CZARNocKA, Kolekcje artystyczne Biblioteki Polskiej w Paryżu, 2012, [w:] Towarzystwo Historyczno-Literackie, Biblioteka Polska w Paryżu, s. 176.

${ }^{73}$ Zob. M.M. GrąBCZewsKa, Zbiór dagerotypów Biblioteki Polskiej w Paryżu, „Rocznik Historii Sztuki” 32(2007), s. 125-154; TAŻ, „, Miscellanea photographica”: narodziny języka fotografii, „Teksty Drugie” 2013, nr 4, s. 13-29. 
artystów lub ich spadkobierców: Konstantego Brandla, Bolesława Biegasa, Jana Ekierta, Georges'a Van Haardta (Józefa Brodnickiego).

W THL/BPP znajduje się kolekcja 500 plakatów, w tym kilka cennych z początku XX wieku, a także zbiory numizmatyczne, w 1926 r. liczące 1700 monet polskich (łącznie z dwoma złotymi dukatami z XVI wieku) ${ }^{74}$, i kilkadziesiąt medali srebrnych i brązowych. Jednakże po stratach wojennych zainicjowano tworzenie kolekcji ze względu na spływające liczne dary. Obecnie trwają prace nad inwentaryzacją zbiorów i opracowaniem naukowym.

Archiwum fotograficzne założone w latach 1931-1932 obejmowało 1500 klisz ułożonych tematycznie. Aktualnie zbiór liczy kilka tysięcy eksponatów. Od kilku lat prowadzone są prace inwentaryzacyjne, ze zbioru wydzielono materiały ikonograficzne. Stanowią je klisze, negatywy szklane, odbitki wykonane różnymi technikami fotograficznymi, 21 dagerotypy - posiadające jednocześnie cenną wartość artystyczną i stanowiące materiał źródłowy do badań nad historią emigracji polskiej. Przedstawiają portrety emigrantów, widoki miast, pejzaże, sceny z życia codziennego, wizerunki artystów, dokumentują dawne ekspozycje, zdjęcia atelier.

W oddzielnych tekach zebrano dokumentację artystyczną, w których przechowywane są informacje dotyczące życia na emigracji i działalności artystów pochodzenia polskiego lub obcych sympatyzujących z Polską.

Dzięki wsparciu finansowemu ze strony Kancelarii Prezydenta RP, w latach 2006-2007 odrestaurowano obiekty ikonograficzne związane z osobą Tadeusza Kościuszki (obrazy, rysunki, rzeźby), a także sztandar Towarzystwa Gimnastycznego „Sokół”. Odnowiono jeden zachowany w całości atlas, 20 s. frontyspisowych z atlasów z XVII i XVIII wieku oraz 40 cennych rycin z widokami i panoramami miast dzięki dotacji Wspólnoty Polskiej. W ramach realizacji Programu Ministra Kultury i Dziedzictwa Narodowego „Dziedzictwo kulturowe”, Priorytet 3. „Ochrona dziedzictwa narodowego poza granicami kraju”, specjaliści z Zakładu Konserwacji Biblioteki Narodowej przeprowadzili ekspertyzy i harmonogram prac konserwatorskich m.in. dla Biblioteki Polskiej w Paryżu ${ }^{75}$ w 2008 r. Podjęto się odrestaurowania i konserwacji 19 rysunków, wśród nich m.in. prac: Olgi Boznańskiej, Jana Matejki, Stanisława Witkiewicza, i 29 rycin, m.in. Tytusa Malczewskiego, Antoniego Oleszczyńskiego i Henryka Redlicha. W dn. 19 listopada 2009 r. zaprezentowano w BN odrestaurowane mapy z XV i kolejnych wieków oraz unikalne

${ }^{74}$ Więcej: M. MęCLEWSKA, Zbiór rzeczy narodowych. Dawne i nowe kolekcje numizmatyczne Biblioteki Polskiej w Paryżu, [w:] Towarzystwo Historyczno-Literackie, Biblioteka Polska w Paryżu, s. 301-308.

75 Sprawozdanie Biblioteki Narodowej za rok 2008, s. 129, 134. 
wydawnictwa $\mathrm{z}$ okresu wojny należące do zbiorów BPP. Prace konserwatorskie 69 map wykonano w Zakładzie Konserwacji Masowej Zbiorów Bibliotecznych, Zakładzie Konserwacji Zbiorów Bibliotecznych i w Laboratorium Konserwatorskim Zbiorów Bibliotecznych BN oraz ich digitalizację, a koszta konserwacji pokryło Ministerstwo Kultury i Dziedzictwa Narodowego ${ }^{76}$. W 2008 r. odrestaurowano 35 gipsowych rzeźb różnych artystów. Muzeum Narodowe w Gdańsku w 2008 r. przeprowadziło konserwację 41 obrazów i rzeźby B. Biegasa, dwóch mebli z atelier artysty i tkaniny wykonanej według jego projektu. Odnowione prace zaprezentowano na wystawie „Zbiory artystyczne Biblioteki Polskiej w Paryżu. Odsłona pierwsza - Bolesław Biegas" w 2009 r. W kolejnym roku ta sama instytucja odrestaurowała 91 obrazów i jedną rzeźbę. Prace udostępniono na wystawie „Zbiory artystyczne Biblioteki Polskiej w Paryżu. Odsłona druga - Artyści polscy w Paryżu". Natomiast w 2011 i 2012 r. pracy konserwatorskiej poddano ryciny i obrazy o tematyce królewskiej oraz cenne ryciny z XVII i XVIII wieku, głównie niemieckie i holenderskie. Ochroną konserwatorską BN objęła około 60 prac z dziedziny kartografii, a także ryciny i rysunki, dzięki wsparciu MKiDzN. Dzięki współpracy z Institut national du patrimoine we Francji zakonserwowano pastelowy portret Marii, córki Władysława Mickiewicza, malarki Klementyny Mien, sześć rycin na pergaminie wykonanych przez Feliksa Jasińskiego oraz wiele obiektów fotograficznych ${ }^{77}$.

\section{MUZEM BOLESŁAWA BIEGASA / MUSÉE DE BIEGAS W ROKU 2008/2009}

Artysta spisał testament w kwietniu 1950 r., w którym ofiarował THL wszystkie swoje obrazy i rzeźby znajdujące się w jego pracowni, stanowiącej zarazem jego mieszkanie. Z prac Bolesława Biegasa utworzono w THL/BPP wystawę stałą Muzem Biegasa / Musée de Biegas, w którym prezentowane są kolekcje prac artysty, zebrane przez Kamila Gronkowskiego, pełniącego funkcję prezesa THL w latach 1946-1949. Składają się na nie: rzeźby gipsowe, w drewnie, terakocie, brązie, obrazy - charakterystyczne malarstwo sferyczne, rysunki, tkaniny wykonane według projektu artysty, zdobione samodzielnie meble z pracowni, a także prace

${ }^{76}$ Pokaz zbiorów z BP z Paryża i POSK z Londynu konserwowanych w BN, http://www. bn.org.pl/aktualnosci/1351-pokaz-zbiorow-z-paryza-i-londynu-konserwowanych-w-bn.html [dostęp: 19.11.2009]; Sprawozdanie Biblioteki Narodowej za rok 2009, Warszawa 2010, s. 21, 78. Zob. A. Czarnocka, Kolekcje artystyczne Biblioteki Polskiej w Paryżu, 2012, s. 177.

77 A. Czarnocka, Kolekcje artystyczne Biblioteki Polskiej w Paryżu, 2012, s. 177. 


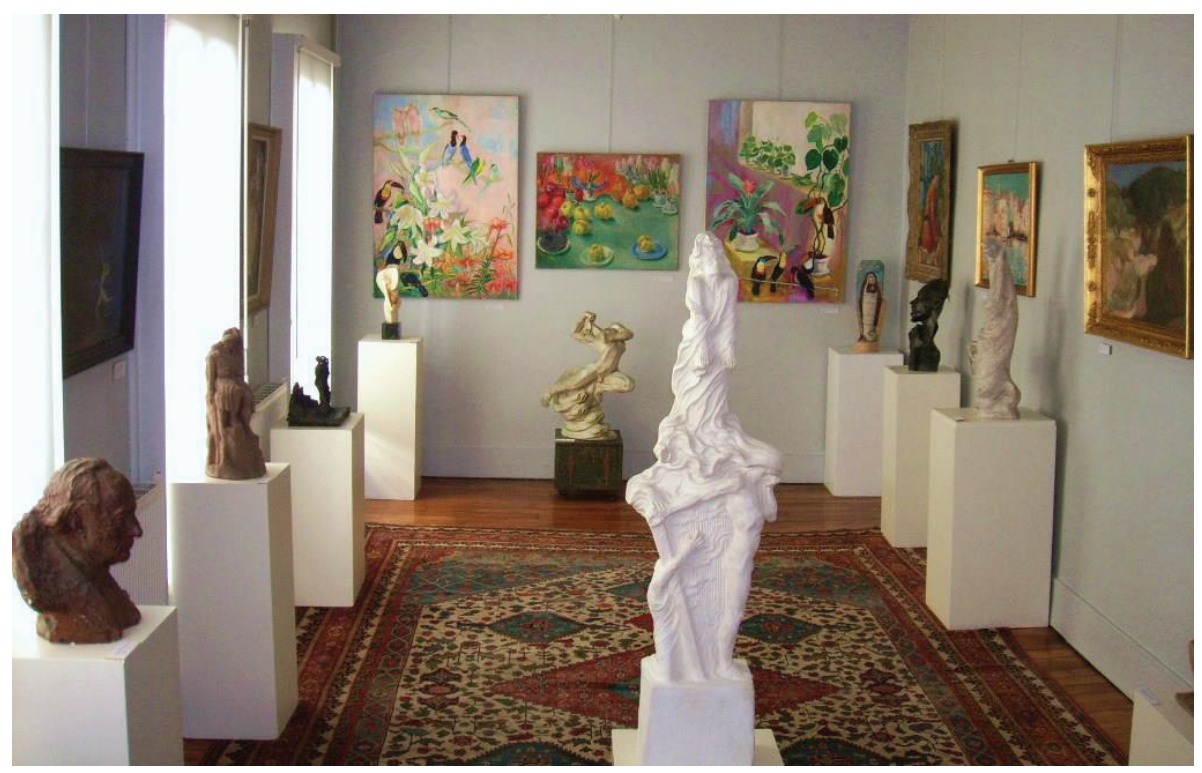

Wnętrze sali wystawowej Muzeum Biegasa / Musée de Biegas w budynku Biblioteki Polskiej w Paryżu w 2008/2009 r. Fot. Archiwum własne

literackie o tematyce filozoficznej: dramaty. Kolekcję Biegasa uzupełniają prace artystów zaprzyjaźnionych z nim, m.in. Olgi Boznańskiej i Gustawa Gwozdeckiego. Część prac artysty złożono w depozyt w Muzeum Mazowieckim w Płocku, Muzeum Narodowym w Gdańsku, Muzeum Sztuk Pięknych w Lyonie, w Rennes, trafiły także do Musée d'Orsay w Paryżu. Pozostałe po nim pisma, korespondencje, fotografie, utwory dramatyczne, maszynopis niewydanego „Życia na sześciu planetach" (1924-1926) ${ }^{78}$ stanowią znaczący materiał badawczy nad twórczością, profilem osobowym artysty i ludzi świata sztuki z jego epoki.

\section{TOWARZYSTWO HISTORYCZNO-LITERACKIE / BIBLIOTEKA POLSKA W ROKU 2008/2009}

Od 2003 r. funkcję prezesa THL pełni prof. Kazimierz Piotr Lubicz-Zaleski. Prezes administruje Biblioteką Polską razem z powołanymi doradcami. Biblioteką Polską zarządza dyrektor BPP, mając do dyspozycji zespół pracowników. Struktura organizacyjna THL/BPP w roku 2008/2009 przedstawiała się następująco:

78 Tamże, s. 176. 


\section{Prezes THL / Président de la SHLP - prof. Kazimierz Piotr Lubicz-Zaleski}

Doradca prezesa ds. technicznych i finansowych / Conseiller du Président: question techniques et financières $-\mathrm{dr}$ Jean P. Mustelier ${ }^{79}$

Doradca prezesa ds. administracyjnych i prawnych / Conseiller du Président: question administratives et juridiques $-\mathrm{B}$. Bovier-Lapièrre

Doradca prezesa ds. naukowych i imprez kulturalnych, kontaktów z członkami THL / Conseiller du Président: activités scientifiques et culturelles, liaison avec les membres de la SHLP - dr Witold Zahorski

Asystentka prezesa ds. imprez kulturalnych THL, kontaktów z młodymi potencjalnymi członkami THL / Assistante du Président: activités musicales de la SHLP, liaison avec les jeunes members potentiels - Ewa Niemirowicz ${ }^{80}$

Dyrektor BPP / Directuer de la BPP - dr Danuta Dubois ${ }^{81}$

Asystentka dyrektora BPP: Internet i informatyka / Assistante du Directeur: Internet et informatique - Beata Skrzypek

Pracownia Zbiorów Specjalnych: rękopisy i archiwa - odpowiedzialna, współodpowiedzialna za muzea / Manuscrits et Archives: responsable et

79 Wiele się od tamtego czasu wydarzyło. W 2012 r. odszedł Jean Offredo (1944-2012) - członek Rady Administracyjnej THL w latach 1999-2012, natomiast w 2014 r.: J.P. Mustelier, Ewa Niemirowicz. Zob. C.P. ZALESKI, Hommage à Jean Offredo, „6, quai d'Orléans: lettre de la Société Historique et Littéraire Polonaise et de la Bibliothèque Polonaise de Paris" 2012, nr 16, s. 1; P. BŁoŃsKI, Témoignages. Grand frère fidèle [Jean Offredo - przyp. J.O.], tamże, s. 2, http://www.bibliotheque-polonaise-paris-shlp.fr/medias/quai_16_web_2.pdf [dostęp: 29.04.2018]; K.P. ZALESKI, Wspomnienie o Jean-Pierre Mustelier, „6, quai d'Orléans” 2014, nr 18, s. 2, http://www.bibliotheque-polonaise-paris-shlp.fr/medias/quai18PL_2.pdf [dostęp: 29.04.2018]; K.P. ZALESKI, Wspomnienie o Ewie Niemirowicz, „6, quai d'Orléans” 2015, nr 19, s. 2, http://www.bibliotheque-polonaise-paris-shlp.fr/medias/ 6QUAI19PL_web_2.pdf [dostęp: 29.04.2018].

${ }^{80}$ Obecna struktura Société Historique et Littéraire Polonaise/SHLP= Towarzystwo Historyczno-Literackie/THL dostępna jest na stronie internetowej THL/BPP, http://www.bibliotheque-polonaise-paris-shlp.fr/index.php?id_rubrique=1136\# [dostęp: 29.07.2018].

${ }^{81}$ Danuta Dubois funkcję dyrektora BPP pełniła od jesieni 2007 do końca 2012 r. „Obecnie znowu dyrektorem Biblioteki Polskiej w Paryżu i prezesem Towarzystwa Historyczno-Literackiego jest Kazimierz Piotr Lubicz-Zaleski”. Zob. LuBICZ-ZALESKI, Aneks, s. 15-16. Aktualna struktura organizacyjna: prezes THL/dyrektor BPP - prof. K.P. Lubicz-Zaleski, delegowani dyrektora: M.T. Vido-Rzewuska, A. Dembiński, asystentka prezesa THL/dyrektora BPP - K. Biedrzycka, attaché Dyrekcji - B. Skrzypek, Pracownia Zbiorów Specjalnych: rękopisy i archiwa - odpowiedzialna E. Rutkowska, Pracownia Kolekcji Artystycznych - odpowiedzialna A. Czarnocka, Salle de lecture - odpowiedzialna M. Głodek, dyrektor pomocniczy BPP - W. Zahorski, Ochrona i monitoring - Ph. Legru, magazynier - P. de Toffoli. Aktualny schemat organizacyjny THL/BPP zamieszczony jest na stronie internetowej THL/BPP pod wskazanym linkiem, http://www.bibliotheque-polonaise-paris-shlp.fr/medias/ ORGANIGRAMME_2015_2.pdf [dostęp: 29.04.2018]. 
coresponsable des musées - Ewa Rutkowska (zespół: Wiesław Filipczyk, Elżbieta Pajor, Arkadiusz Roszkowski)

Pracownia Kolekcji Artystycznych - odpowiedzialna, współodpowiedzialna za muzea / Collections Artistiques: responsable et coresponsable des musées - dr Anna Czarnocka (zespół: Małgorzata Grąbczewska, Paweł Ignaczak)

Książki, Druki, Czasopisma / Livres, imprimés, journaux - odpowiedzialna p.o. dr Danuta Dubois (zespół bibliotekarzy: Danuta Adamowicz i Dorota Filip z Wrocławia, Anna Polańska z Krakowa, Joanna Okarma z Warszawy, Magdalena Głodek i Katarzyna Thomas z Paryża; zatrudnione w innym wymiarze czasowym: Anna Bober i Lucyna Pyrzowska z Krakowa, Grażyna Wójcik z Wrocławia)

Magazynier / Magasinier - Pascale de Toffoli

Logistyka / Logistique - odpowiedzialny Jean Goanvic, adjoint - Philip Legru; M. Emen, M. Baradji.

Zbiory BPP udostępniane są, w zależności od potrzeb czytelnika czy osoby zainteresowanej, w trzech pracowniach: Czytelni / Salle de Lecture, Pracowni Zbiorów Specjalnych / Salle des Chercheurs i Pracowni Kolekcji Artystycznych / Collection Artistique. Biblioteka Polska w Paryżu była dostępna w godzinach:

Czytelnia / Salle de Lecture - wtorek, czwartek, piątek 14:15-17:45; sobota 9:00-13:00

Pracownia Zbiorów Specjalnych / Salle des Chercheurs - poniedziałek-piątek 10:15-12:45; 14:15-17:45

Muzea (zwiedzanie z przewodnikiem) / Musées (visites guidées) - środa 14:1518:00; sobota 9:15-13:0082.

Po kilku miesiącach - odpowiadając na potrzeby użytkowników - Czytelnia / Salle de Lecture otworzyła swe wrota we wskazane dni także przed południem ${ }^{83}$.

82 Przy okazji obchodów 200. rocznicy urodzin F. Chopina w 2010 r. poddano zmianie dotychczasową lokalizację i aranżację eksponatów wystaw stałych wszystkich trzech muzeów, sytuując je na pierwszym piętrze gmachu Biblioteki Polskiej. Na parterze budynku znajdują się sale wystaw czasowych. Funkcjonowanie muzeów i grupy odbiorców szerzej opisuje: P. IGNACZAK, Muzea w Bibliotece Polskiej w Paryżu, „Muzealnictwo” 2016, nr 57, s. 226-233.

${ }^{83}$ Aktualnie Biblioteka Polska w Paryżu jest otwarta dla zainteresowanych według harmonogramu: Salle de lecture / Czytelnia od środy do soboty w godz. 14:15-18:00 z wyjątkiem dni świątecznych i wolnych od pracy, Salle des chercheurs / Pracownia zbiorów specjalnych od wtorku do piątku w godz. 9:15-13:00 i 14:15-18:00, Musées / Muzea od środy do soboty 14:15-18:00, http://www. bibliotheque-polonaise-paris-shlp.fr/index.php?id_rubrique=21129\%3e. [dostęp: 29.07.2018]. 


\section{CZYTELNIA / SALLE DE LECTURE}

Z czasem archiwa i dary napływały od polskich emigrantów lub ich potomków z innych krajów, a nawet z innych kontynentów; zaś z Polski przesyłane były i nadal są przez autorów, księgarzy oraz wydawnictwa. W ostatnich latach część zbiorów udało się pozyskać na drodze wymiany międzybibliotecznej, prowadzonej głównie z bibliotekami naukowymi i akademickimi przede wszystkim z Polski, ale także z Francji i Wielkiej Brytanii oraz bezpośrednio od wydawców.

Na zbiory druków zwartych i ciągłych zgromadzonych w BPP składają się przede wszystkim XIX- i XX-wieczne dzieła z dziedziny: historii, nauk politycznych, geografii, ekonomii, nauk społecznych, demografii, statystyki, prawa, etnografii, socjologii, literatury, historii literatury, historii nauk, filozofii i kultury polskiej. Tematyka zbiorów poszerzona jest o oficjalne wydania państwowe i międzynarodowe, o literaturę naukową związaną z Polską Akademią Umiejętności oraz dotyczącą polskiej emigracji, o wydawnictwa THL i Biblioteki Polskiej w Paryżu, np. „Akta Polskiego Towarzystwa Historyczno-Literackiego".

W 1848 r. szacunkowy stan księgozbioru i czasopism obliczono na 25 tys. tomów, a w 1893 r.: 42 tys. tomów, zaś w 1912 r. według Strzembosza było ich ponad 80 tys. woluminów. W latach 20 . XX wieku przeliczono liczbę półek na metry, przy czym przyjęto, że na półce mieści się średnio 30 książek na metr bieżący, to otrzymano 65 tys. tomów na stanie.

Do roku 2000 zbiory z Czytelni / Salle de Lecture mieściły się na parterze, a po ostatnim remoncie w latach 2000-2004 Czytelnia została przeniesiona na drugie piętro $^{84}$ i przygotowana dla czternastu stanowisk pracy.

Zbiory książek w BPP liczą ponad 200 tys. woluminów w różnych językach, głównie w jęz. polskim, trochę mniej w jęz. rosyjskim, jęz. francuskim, jęz. angielskim, jęz. niemieckim i innych. Do najcenniejszych należą też zbiory najstarszych czasopism polskich i emigracyjnych z wieków XVIII-XX, rzadko dostępnych albo niedostępnych w Polsce, około 1 tys. tytułów, wymieńmy chociażby: „Narodowiec”, „Kurier Warszawski”, „Kurier Poznański”, roczniki „Czasu” lub „Ilustrowany Kurier Codzienny” z Krakowa czy „Słowo Polskie” wydawane we Lwowie. Te i inne czasopisma obecnie są udostępniane czytelnikom do konsultacji na miejscu w BPP w postaci mikrofilmów. W ramach Programu Ministra Kultury i Dziedzictwa Narodowego „Dziedzictwo kulturowe”. Priorytet 3. „Ochrona dziedzictwa narodowego

${ }^{84}$ Por. tekst byłego dyrektora BPP Witolda Zahorskiego: W. ZAHORsKI, Charakterystyka księgozbioru Biblioteki Polskiej w Paryżu, http://www.bibliotheque-polonaise-paris-shlp.fr/medias/ TEKSTW.ZPL.pdf [dostęp: 29.10.2009]; TENŻE, Charakterystyka księgozbioru Biblioteki Polskiej w Paryżu, [w:] Towarzystwo Historyczno-Literackie, Biblioteka Polska w Paryżu, s. 95-97. 
poza granicami kraju" pracownicy Biblioteki Narodowej zeskanowali i zgrali na nośniki DVD zmikrofilmowane dla BPP czasopisma ${ }^{85}$. Nieoceniona wartość i ilość zbiorów BPP uplasowała ją jako najbogatszą bibliotekę polską poza granicami kraju. Ten przywilej sprawił, że została współzałożycielem Stałej Konferencji Muzeów, Archiwów i Bibliotek Polskich na Zachodzie (Stała Konferencja MABPK, http:// biblioteka.info/mabpk/ $)^{86} \mathrm{~W}$ Muzeum Polskim w Rapperswilu w $1977 \mathrm{r}{ }^{87}$

Przez wiele lat oddani bibliotekarze, czy to zatrudnieni pracownicy, czy wolontariusze, po przyjęciu ofiarowanych książek katalogowali je wyłącznie na kartach katalogowych i składowali w drewnianych katalogach kartkowych ${ }^{88}$. Od 2005 r. Biblioteka kataloguje swoje zbiory wyłącznie elektronicznie w systemie VTLS/ Virtua i jako pierwsza biblioteka polonijna uczestniczy w procesie współkatalogowania w katalogu centralnym NUKAT ${ }^{89}$. Porozumienie o współpracy obie strony podpisały w Warszawie w październiku 2008 r. ${ }^{90}$ Do roku 2008 skatalogowane

85 Sprawozdanie Biblioteki Narodowej za rok 2008, Warszawa 2009, s. 129, http://www.bn.org. pl/download/document/1241790645.pdf [dostęp: 09.12.2009].

${ }^{86}$ Najprawdopodobniej od grudnia 2015 r. Stała Konferencja (MABPZ) dysponuje nowym adresem strony internetowej, http://mabpz.org/ [dostęp: 29.04.2018].

${ }^{87}$ W latach 2006-2009 prof. Barbara Bieńkowska z zespołem zrealizowała projekt na zlecenie Departamentu Dziedzictwa Kulturowego Ministerstwa Kultury i Dziedzictwa Narodowego, polegający na stworzeniu bazy danych zagrożonych polonijnych zbiorów bibliotecznych. Zliczono ponad 2 tys. polonijnych instytucji i organizacji emigracyjnych na wszystkich kontynentach, które posiadają zbiory różnego typu, ale mające znaczenie dla polskiego dziedzictwa kulturowego. Systematyczną współpracę Ministerstwo Kultury i Dziedzictwa Narodowego podjęło z około 30 największymi organizacjami i instytucjami polonijnymi na emigracji, od 2006 r. prowadząc ją za pośrednictwem różnych specjalistów z instytucji podległych Ministerstwu i znacząco zwiększając nakłady na ochronę dziedzictwa polskiego za granicą. Większość dużych polskich organizacji emigracyjnych jest zrzeszona w Stałej Konferencji Muzeów, Archiwów i Bibliotek Polskich na Zachodzie. Zob. J. MiLer, Biblioteka Polska w Paryżu na tle polskich instytucji emigracyjnych, [w:] Biblioteka Polska w Paryżu - skarbnica kultury narodowej: materiaty, s. 46n, 49 (dokument elektroniczny). W 2015 r. Stała Konferencja MABPZ skupiała 21 instytucji polonijnych działających w Europie, Ameryce Płn. i Pdn. oraz Australii i F. Ziejka wymienia je z nazwy. Zob. F. ZieJKa, Skarby kultury polskiej, s. 23.

${ }^{88}$ O polskiej „Bibliotece Narodowej” w Paryżu i jej zasługach napisano już wiele. Do dziejów THL/BPP ważkie informacje wnoszą ich publikacje własne. Zob. A. GAŁKowski, H. KRAsowSKA, Biblioteka Polska w Paryżu - przegląd historiografii, „Nauka Polska” (Warszawa) 24(2015), s. 105-119.

${ }^{89}$ Por. Narodowy Uniwersalny Katalog Centralny NUKAT, http://www.nukat.edu.pl/ [dostęp: 29.10.2009].

${ }^{90}$ Biblioteka Polska w Paryżu w NUKAT, http://www.ebib.info/content/view/1593/202/ [dostęp: 29.10.2009]; M. MatuszewsKa, Biblioteka Polska jest otwarta dla czytelników, „Gazeta Wrocławska” 18 grudnia 2010, https://gazetawroclawska.pl/biblioteka-polska-jest-otwarta-dla-czytelnikow/ ar/346947 [dostęp: 29.04.2018]. Por. A. KAnia, D. DomalewsKa, Spotkanie Dyrektorów i Bibliotekarzy Systemowych Bibliotek wspóttworzacych NUKAT [w BUW, Warszawa 5 grudnia 2014 r.], https:// 
elektronicznie w BPP pozycje były włączone i dostępne poprzez portal Katalog 7-Bibliotek Krakowskich (naukowych i akademickich), który z czasem się poszerzył na Katalog 8-Bibliotek Krakowskich (http://katalog.pwst.kzb.krakow.pl/)91. W celu wyszukania odpowiednich pozycji czytelnik wybierał z listy lokalizację przeszukiwanego zasobu wybranej Biblioteki. Wśród nich były dostępne poszczególne pracownie BPP, a co za tym idzie - odpowiednie kolekcje. Od 2009 r. BPP posiadała wyodrębniony z NUKAT własny katalog elektroniczny, który w znacznie łatwiejszy sposób pozwalał na wyselekcjonowane przeglądanie zbiorów, oddzielnie druków zwartych i ciągłych (http://katalog.bpp.kzb.krakow.pl/) $)^{92}$. Poza tym, na stronie internetowej zamieszczono dodatkowo wykaz tytułów czasopism zmikrofilmowanych. Na wybranym stanowisku komputerowym w Czytelni Biblioteki Polskiej umożliwiono dostęp do zeskanowanego katalogu kartkowego ${ }^{93}$, który z pewnością jest wygodniejszym i sprawniejszym narzędziem w przeszukiwaniu katalogu, niż czasochłonne przeglądanie papierowych kart katalogowych.

W ramach współpracy bilateralnej Biblioteka Uniwersytetu Jagiellońskiego przeprowadziła na rzecz BPP prace odkwaszania i oprawy kompletu paryskiej „Kultury” w 2009 r. Kolekcja ta już trafiła na właściwe sobie miejsce w Czytelni BPP.

\section{INTERSUBIEKTYWNA INTERPRETACJA ŻYCIA CODZIENNEGO THL/BPP, CZYLI MOJE DOŚWIADCZENIA ZAWODOWE W BPP W ROKU 2008/200994}

W 2008 r. zostałam zatrudniona przez PAU na stanowisku bibliotekarza i oddelegowana do pracy w THL/BPP. Prezes THL Kazimierz Piotr Lubicz-Zaleski

bg.uek.krakow.pl/biblioteka/biuletyn/artykuly.php?Strona=Art\&Wybor=44\&Art=ks_nukat [dostęp: 29.04.2018].

${ }^{91}$ Aktualnie Krakowski Zespół Biblioteczny (KZB) współtworzy 14 instytucji, http://www.kzb. krakow.pl/index.php?p=kzb [dostęp: 29.04.2018].

${ }_{92}$ Po 2009 r. reaktywowano katalog elektroniczny BPP, który aktualnie zawiera skatalogowanych 41190 woluminów, https://katalogkrak.cyfronet.pl/search/query?theme=BPP [dostęp: 29.04.2018] Informacja zaczerpnięta ze strony internetowej THL/BPP, http:/www.bibliotheque-polonaise-paris-shlp.fr/index.php?id_rubrique=21113 [dostęp: 29.04.2018].

${ }_{93}$ Po 2009 r. zeskanowany katalog kartkowy udostępniono ze strony internetowej BPP, http://62.23.96.204:9000/webconsultation/skins/default_gray/findex.jsp [dostęp: 29.04.2018]. Również po 2009 r. studenci i pracownicy Instytutu Informacji Naukowej i Studiów Bibliologicznych Uniwersytetu Warszawskiego rozpoczęli retrokonwersję katalogu kartkowego BPP [Fond Ancien] w systemie MAK, który zawiera 3500 opisów według formatu MARC21, http://193.0.122.72/cgi-bin// makwww.exe?BM=1 [dostęp: 29.04.2018]. Informacje zaczerpnięte ze strony internetowej THL/BPP, http://www.bibliotheque-polonaise-paris-shlp.fr/index.php?id_rubrique=21113 [dostęp: 29.04.2018].

${ }^{94}$ Por. publikację opisującą szerszy zakres czasowy za pomocą obiektywu fotograficznego. B. Konopka, Bibliothèque Polonaise de Paris / Biblioteka Polska w Paryżu 1993/2012, Paris 2013. 
i dyrektor BPP Danuta Dubois miło powitali i przyjęli nowych pracowników pochodzących z różnych polskich instytucji: bibliotek naukowych i akademickich ${ }^{95}$. W konsekwencji powstał kilkuosobowy polsko-francuski zespół bibliotekarski. Zastałam budynek Biblioteki Polskiej zadbany, odremontowany, z regałami kompaktowymi, regulacją temperatury i kontrolą wilgotności w magazynach, spełniający estetyczne połączenie zabudowania historycznego z nowoczesnością. Po rekonesansie i rozeznaniu doświadczeń zawodowych przybyłych, jak i miejscowych pracowników, przyjęliśmy podział zadań.

Zaplanowane prace toczyły się według przyjętego porządku poprzedniej ekipy bibliotekarskiej. Jedna z osób z poprzedniej ekipy pracowników - Grażyna Wójcik z Wrocławia, zatrudniona dłużej w BPP - wprowadzała nowy zespół pracowników. Zachowano, jak w każdej bibliotece, praktykę prowadzenia księgi akcesyjnej i księgi inwentarzowej dla bieżącego wpływu.

Sprawa opracowania elektronicznego stanowiła przedmiot priorytetowy THL/ BPP, zatem większa część bibliotekarzy podjęła się katalogowania elektronicznego druków zwartych i druków ciągłych ${ }^{96}$. Prowadzono Czytelnię / Salle de Lecture, przyjmowano czytelników, naukowców i badaczy. Równolegle przykładano troskę do selekcji dubletów/tripletów/wieloegzemplarzowości ${ }^{97}$ i wymiany międzybibliotecznej, zarówno druków zwartych, jak i ciągłych. Wymiana międzybiblioteczna pozwalała na pozyskanie wolnych powierzchni magazynowych (półek i regałów) na składowanie przyszłych księgozbiorów i rezerw wydawnictw własnych. Zgodnie z przyjętą polityką gromadzenia druków zwartych przez THL/BPP z czerwca 2008 r., przypadła mi w udziale kontynuacja działań operacyjnych związanych z: wymianą międzybiblioteczną druków zwartych (sporządzanie spisu dubletów i zbędnych druków zwartych, przygotowanie list dubletów/zbędnych druków zwar-

${ }^{95}$ Zob. pełny wykaz pracowników THL/BPP i delegowanych przez PAU do BPP. A. MichALEwICZ, Wspótpraca Polskiej Akademii Umiejętności z Towarzystwem Historyczno-Literackim, [w:] Wspólna sprawa. Studia i materiaty do dziejów emigracji polskiej we Francji, Kraków 2017, s. 159-169.

${ }^{96}$ Prace katalogowania elektronicznego kontynuowano w następnych latach. Zob. M. GŁODEK, Narodowy Program Rozwoju Humanistyki szansq dla Biblioteki Polskiej w Paryżu, „6, quai d'Orléans" 2014, nr 18, s. 21-22, http://www.bibliotheque-polonaise-paris-shlp.fr/medias/quai18PL_2.pdf [dostęp: 29.04.2018]. Zob. opis realizacji projektu opracowania katalogu elektronicznego XIX-wiecznych druków ze zbiorów THL/BP w Paryżu w zintegrowanym systemie bibliotecznym VTLS/Virtua w latach 2013 - 31 lipca 2016. L. Pyrzowska, Projekt badawczy Polskiej Akademi Umiejętności „Opracowanie katalogów XIX-wiecznych druków wydanych na emigracji i ziemiach polskich za granica ze zbiorów Biblioteki Polskiej i Towarzystwa Historyczno-Literackiego w Paryżu”, [w:] Wspólna sprawa. Studia i materiaty, s. 177-181.

${ }^{97}$ Por. opis dwutygodniowych doświadczeń w Bibliotece Polskiej ekipy przybyłej z Warszawy. Z. Byczkowska, Dublety Biblioteki Polskiej w Paryżu, „Biuletyn Informacyjny Biblioteki Narodowej" 2000 , nr 4, s. 26-28. 
tych, wysyłka list dubletów/zbędnych druków zwartych, przyjmowanie zamówień od bibliotek, koordynowanie przygotowań i przekazu/wysyłek zamówionych publikacji), kontakty z bibliotekarzami, ofiarodawcami instytucjonalnymi i osobami prywatnymi, wydawnictwami - w tym utrzymanie i nawiązanie nowych - w celu pozyskania nabytków.

Z przejętych po poprzedniej ekipie pracowników 16 kontaktów z polskimi bibliotekami z czasem okazało się, że jedynie $9 \mathrm{z}$ nich aktywnie uczestniczyło we współpracy. W toku pracy w roku 2008/2009 nawiązano kolejnych 12 obiecujących kontaktów z bibliotekami naukowymi i akademickimi oraz innymi instytucjami. Prowadzono stałą współpracę z 21 instytucjami w ramach wymiany międzybibliotecznej, głównie z Polski. W tym, w ramach współpracy, nawiązano kontakty $\mathrm{z}$ trzema bibliotekami francuskimi o profilu słowiańskim: Bibliothèque Nationale de France, Centre d'études slaves, CNRS-Paris IV Sorbonne, Bibliothèque de Langues Romanes, Slaves et Orientales, Université Charles-de-Gaulle - Lille 3. W trakcie pracy w BPP w roku 2008/2009 udało się przeprowadzić i zrealizować 21 list dubletów i zbędnych druków zwartych. Na prośbę dyrekcji BPP spis dubletów i zbędnych druków zwartych pogrupowano według działów klasyfikacji UKD. W sumie przekazano lub przesłano do instytucji 1897 woluminów zamówionych z proponowanych list dubletów i zbędnych druków zwartych BPP. Wielkość wymiany międzybibliotecznej BPP zaprezentowano na wykresie 1 .

$\mathrm{Z}$ danych na przedstawionym wykresie wynika, iż instytucje polskie (naukowe $i$ akademickie) zdecydowanie bardziej były zainteresowane przyjmowaniem dubletów BPP niż instytucje francuskie. Po zachowaniu pierwszeństwa zamówień od Biblioteki Narodowej w Polsce, najwięcej dubletów przyjęła Biblioteka UKSW. Kolejno uplasowały się: Biblioteka UMK, Biblioteka PAU i PAN w Krakowie, Biblioteka Uniwersytecka w Warszawie ${ }^{98}$. Dużym zainteresowaniem cieszyły się, praktycznie niedostępne w Polsce, rzadkie patriotyka emigracyjne i publikacje dawne, szczególnie z okresu sprzedwojnia i międzywojnia.

Przekazywano w darze większości partnerom THL/BPP aktualne wydawnictwo własne THL/BPP pt.: „6, quai d'Orléans: lettre de la Société Historique et Littéraire Polonaise et de la Bibliothèque Polonaise de Paris", które cieszyło się wielkim zainteresowaniem.

${ }^{98}$ W zakresie współpracy wymiennej odstąpiono od zasady książka za książkę. Jak już zostało wspomniane, celem nadrzędnym w konkretnych przypadkach stała się promocyjna rola THL/BPP w popularyzacji języka, historii, kultury polskiej i/lub poloników zagranicznych, z jednoczesnym wygospodarowaniem nowych przestrzeni magazynowych, za to kosztem pominięcia zachowania zrównoważonej wymiany. Por. H. KęSICKA, Międzynarodowa wymiana materiałów bibliotecznych, „Biuletyn Informacyjny Biblioteki Narodowej” 2000, nr 4, s. 17, 20. 


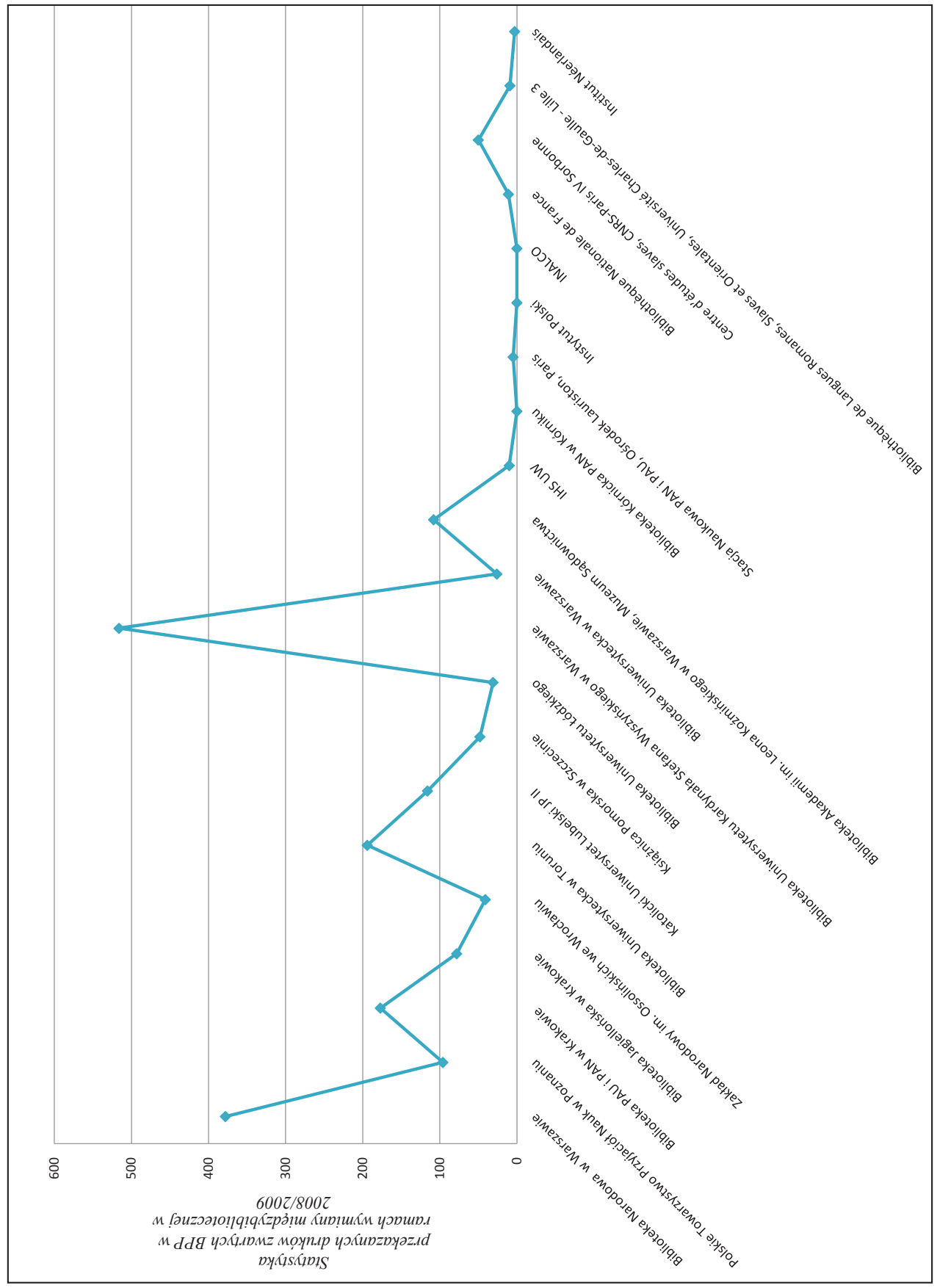

Wykres 1 . Wymiana międzybiblioteczna BPP z poszczególnymi partnerami w roku 2008/2009 
Z wdzięcznością przyjmowano w BPP przychylne ustosunkowanie się do próśb o dar publikacji wydawców francuskich i instytucji innych niż biblioteki, m.in. Musée Mainssieux we Voiron, Institut Néerlandais / Fondation Custodia w Paryżu, Musée des Beaux-Arts w Dijon, Wydawnictwo Denoël w Paryżu. Pozytywnie także odpowiedzieli polscy wydawcy: Wydawnictwo W.A.B., Wydawnictwo DiG, Wydawnictwo PIW, Spółdzielnia Wydawnicza „Czytelnik” z Warszawy. W opisanym roku przyjęto liczne dary od osób prawnych i osób fizycznych, np. z Instytutu Polskiego, od organizacji polonijnej Amicale Polonaise de Dauphiné z Grenoble, Biblioteki Polskiej POSK w Londynie / Polish Library, Muzeum Polskiego w Rapperswilu, Special Collections Research Center The University of Chicago Library, dar pana Dwernickiego i innych osób. Z Polski również napływały dary od osób prywatnych i instytucji. Swoje dary ofiarowały m.in.: Biblioteka Muzeum Narodowego w Warszawie, Muzeum Niepodległości w Warszawie, Narodowe Archiwum Cyfrowe, Muzeum Narodowe w Krakowie, Państwowe Zbiory Sztuki na Wawelu, Zamek Królewski na Wawelu, Instytut Sztuki PAN, Towarzystwo Muzyczne im. Fryderyka Chopina w Warszawie, Kancelaria Sejmu RP, IPN Warszawa, IPN Gdańsk, Wojewódzki Ośrodek Kultury w Bydgoszczy, Fundacja św. Andrzeja Boboli, Wydawnictwo Księży Misjonarzy. Należy zaznaczyć fakt, że część darów włączono do księgozbioru BPP, natomiast pozostała część okazała się dubletami lub tematycznie niezwiązana $\mathrm{z}$ profilem biblioteki. W takich sytuacjach dane pozycje były przeznaczane jako druki zbędne i kierowane na wymianę międzybiblioteczną. Współpraca w ramach wymiany międzybibliotecznej zaowocowała wieloma niespodziewanymi i satysfakcjonującymi rozwiązaniami. Zdarzało się, że biblioteki na złożone zapytanie o pozyskanie interesującej nas pozycji angażowały się w jej poszukiwanie na rynku antykwarycznym lub dokonywały zakupu, albo też uruchamiały swoje kontakty w celu pozyskania danego dzieła dla THL/BPP.

Praca $\mathrm{w}$ zakresie wymiany wiązała się także z pozyskiwaniem publikacji pochodzących z list dubletów nadsyłanych przez biblioteki. Przysłaną listę propozycji publikacji należało sprawdzić pod kątem profilu BPP, a potem zweryfikować obecność tego druku w katalogu elektronicznym i/lub nie/ w katalogach kartkowych. Sprawdzenie odpowiedniego typu katalogu zależało od roku wydania dzieła. Najnowsze książki wystarczyło sprawdzić jedynie w katalogu elektronicznym. Publikacje wydane przed rokiem 2005 należało zweryfikować w katalogach kartkowych. Rok 2005 był datą graniczą, od którego rozpoczęto katalogowanie elektroniczne w THL/BPP. Uprzednia weryfikacja w katalogach była czynnością konieczną do wykonania, po to, by nie zamówić drugiego lub kolejnego egzemplarza tej samej pozycji. Zajęcie to okazywało się dość żmudne, bowiem pracę tę trzeba było wykonać dość sprawnie i w możliwie krótkim czasie, tak by zdążyć zamówić 
interesujące pozycje dosyć wcześnie, przed innymi bibliotekarzami. Przypomnę, iż propozycja listy dubletów wysyłana była do kilku lub kilkunastu bibliotek naraz. Pierwszeństwo w zamówieniu miała Biblioteka Narodowa, ze względu na powierzone jej zadania statutowe, a potem obowiązuje zasada przydziału „kto pierwszy ten lepszy". Przesyłane propozycje list dubletów pochodzących od bibliotek konsultowane były z innymi bibliotekarzami i pracownikami BPP: Salle des Chercheurs i Collection Artistique w celu wyboru interesujących publikacji. Wymiana międzybiblioteczna była najpewniejszym sposobem pozyskiwania nabytków, bowiem THL/BPP sporadycznie dokonywało zakupów. THL/BPP w ramach darów i wymiany pozyskało 507 pozycji.

Czas oczekiwania na zgłoszenia zamówień bibliotek do realizowanej listy dubletów/ zbędnych druków zwartych BPP przeznaczałam na inne prace: uzupełnianie tworzonego spisu dubletów/zbędnych druków zwartych BPP w arkuszu kalkulacyjnym MS Excel, prace magazynowe i związane z przygotowaniem druków do wysyłki/przekazania. W uzupełnianiu spisu dubletów/druków zwartych THL/BPP swoją wdzięczną pomocą wspomogli w ostatnim czasie bibliotekarze akademiccy z Polski przybywający na staże zawodowe. Niezbędne w pracy okazały się wcześniejsze doświadczenia zawodowe związane $\mathrm{z}$ tworzeniem opisów przedmiotowych druków zwartych według jhp KABA w systemie VTLS/Virtua.

Uzyskano dodatkowe wzmocnienie poczucia wspólnoty wobec poddawanych selekcji zbiorów, zarówno druków zwartych, jak i druków ciągłych, wykonując część prac magazynowych realizowanych z dubletami czasopism: ułożenie tytułów, spisanie numerów roczników i utworzenie spisu dubletów. Włączano się w prace tworzenia rekordu zasobu w systemie VTLS/Virtua.

W ciągu tygodnia za obsługę użytkowników w Czytelni / Salle de Lecture odpowiedzialny był wyznaczony dyżurujący bibliotekarz. Natomiast cotygodniowe sobotnie dyżury w pomoc użytkownikom angażowały cyklicznie personel dwujęzyczny (udzielanie informacji nt. katalogów BPP: kartkowych, elektronicznego, czytnika do mikrofilmów, często nt. katalogów elektronicznych: francuskich i polskich oraz innych baz danych, pomoc w poszukiwaniu materiałów, udzielanie informacji telefonicznej i mailowej, realizacja kwerend).

Z powodu ograniczeń lokalowych moje stanowisko pracy zostało zorganizowane w Czytelni. Nieświadomi moich zadań czytelnicy często kierowali do mnie swoje zapytania. W taki oto sposób zostałam włączona w zajęcia z czytelnikami. Z przeprowadzonych obserwacji wynikało, że około $70 \%$ czytelników była francuskojęzyczna. Jeśli chodzi o kraj pochodzenia, to około 50\% stanowili Polacy (z czego 30\% od dłuższego czasu mieszkający we Francji, a więc znających język francuski), 50\% stanowili Francuzi lub czytelnicy innego pochodzenia: Niemcy, Rosjanie, Japończycy, Amerykanie, osoby z programu międzynarodowej wymiany 
studentów „Sokrates/Erasmus” - poznający historię i kulturę polską, a także poszukujący swych korzeni genealogicznych ${ }^{99}$.

Poszukiwania źródeł czynione w celu realizacji kwerend były okazją, by poznać historie polskich emigrantów. Przeglądając zachowane dokumenty i zgromadzone pamiątki dowiedziałam się, że w przeszłości gmach BPP przy 6, quai d'Orléans spełniał funkcję siedziby towarzystwa zawodowego, np. Towarzystwa Paryskiego Lekarzy Polskich / Société Parisienne des Medecins Polonais (zał. 1858) ${ }^{100}$. Towarzystwo wydawało „Rocznik Towarzystwa Paryskiego Lekarzy Polskich”, w którym publikował swoje pierwsze prace, a potem został czynnym jego członkiem znany we Francji polski lekarz okulista Xawery (lub Ksawery) Gałęzowski (1832-1907).

Przybywający okresowo do THL/BPP naukowcy, badacze, stypendyści, historycy, archiwiści ${ }^{101}$, realizujący na miejscu kwerendy czy granty, wymagali wsparcia „paryskiego" zespołu archiwistów i bibliotekarzy, wzmożonego sprowadzania z magazynów i udostępniania archiwów, rękopisów czy innych materiałów. Miałam przyjemność pełnić dyżury w Salle des Chercheurs / Archiwa i Rękopisy, której zbiory specjalne są pod opieką archiwistów. Specjalny typ dokumentów archiwalnych i rękopiśmiennych, znajomość metod i narzędzi potrzebnych w obchodzeniu się z nimi, inne wymogi udostępniania niż w Czytelni sprawiały, że trafiali tam czytelnicy tacy, jak naukowcy, badacze, pasjonaci.

Życiu codziennemu w THL/BPP towarzyszyły częste wydarzenia naukowe i kulturalne: sympozja, kolokwia, konferencje, odczyty, wernisaże, wystawy czy koncerty muzyki klasycznej i współczesnej organizowane dla członków THL

99 Zdaniem W. Zahorskiego: ,ilość osób odwiedzających Bibliotekę Polską szacuje się na dwatrzy tysiące rocznie. Są to przede wszystkim Polacy przybywający z kraju lub z różnych krajów emigracji, z Francją na czele, ale również cudzoziemcy, profesorowie zagranicznych uczelni (znawcy historii Europy Środkowo-Wschodniej oraz slawiści), młodzież uniwersytecka i szkolna, dziennikarze, osoby poszukujące swych rodzinnych korzeni, stypendyści Towarzystwa Historyczno-Literackiego (Fundusz im. Stanisława Lama - stypendia na prace z zakresu historii literatury polskiej i krytyki literackiej, Fundusz im. Jana i Suzanne Brzękowskich - stypendia na prace z zakresu historii Polski oraz Fundusz im. dr Marii Zdziarskiej-Zaleskiej, z którego przyznawane są stypendia na prace badawcze w Bibliotece Polskiej z zakresu historii, filologii polskiej, historii sztuki, politologii i kartografii historycznej)". W. Zahorski, Księgozbiór Biblioteki Polskiej w Paryżu, [w:] Towarzystwo Historyczno-Literackie, Biblioteka Polska w Paryżu, s. 97.

${ }^{100}$ Cel i Ustawy, Towarzystwo Paryzkie Lekarzy Polskich, Cel i Ustawa, Paryż, dn. 10 kwietnia 1858 r., Zbiory BPP, sygn. 26514 II (1-6); Reaktywowane TPLP: Ustawa Towarzystwa Paryzkiego Lekarzy Polskich, Paryż, dn. 1 marca 1865 r., Zbiory BPP, sygn. 17818 III.

101 Zob. M. KuLECKI, Sprawozdanie z prac archiwalnych w Bibliotece Polskiej w Paryżu, „Miscellanea Historico-Archivistica" 17(2010), s. 263-265; M. KALCZYŃSKA, Refleksje z pobytu na stypendium naukowym w Bibliotece Polskiej w Paryżu, „Biuletyn EBIB” 2009, nr 5 (czasopismo elektroniczne), http://www.ebib.pl/2009/105/a.php?kalczynska [dostęp: 29.04.2018]. 
(i potencjalnych młodych członków THL), które były organizowane w dużej sali konferencyjno-koncertowej Audytorium im. Jana Pawła II na parterze budynku BPP lub na terenie nieruchomości BPP ${ }^{102}$, a także - wspomniane już - wydarzenia społeczności lokalnej, w których uczestniczyło THL/BPP, a zorganizowanie ich motywowało ekipy: administracji, archiwistów, historyków sztuki i bibliotekarzy do zaangażowania, twórczych pomysłów, przygotowania materiałów i współpracy w realizacji podjętych planów ${ }^{103}$. Kilka razy podczas koncertów w ramach podziękowań wykonawcom wręczono $\mathrm{w}$ darze publikacje pochodzące $\mathrm{z}$ dubletów BPP i tematycznie nawiązujące do przeprowadzonej imprezy.

W trakcie rocznego pobytu i pracy w BPP zdobyłam doświadczenie w małej bibliotece naukowej, gdzie pracę organizuje się inaczej w porównaniu z dużą biblioteką. W małej bibliotece nie można mówić o wąskiej specjalizacji - co w dużej jest standardem, wykonuje się różne prace samodzielnie lub zespołowo, czę-

102 W 2009 r. minęła 200 rocznica urodzin członka THL Juliusza Słowackiego (1809-1849), którego pamięci poświęcono w BPP kilka odczytów, kolokwiów oraz „6, quai d'Orléans” 2009, nr 13, s. 9-12, http://www.bibliotheque-polonaise-paris-shlp.fr/medias/13.pdf [dostęp: 29.10.2009]. Biblioteka Polska rozpoczęła przygotowania do obchodów „Roku Chopinowskiego 2010” w 200. rocznicę urodzin polskiego paryżanina - Fryderyka Chopina (1810-1849), przypadającej w 2010 r., o czym powiadomiono w „6, quai d'Orléans” 2009, nr 14, s. 11-13, http://www.bibliotheque-polonaise-paris-shlp.fr/medias/14.pdf [dostęp: 29.10.2009]. Finalizację prac potwierdzają okazyjne publikacje: Chopiniana in the collections of the Polish Historical and Literary Society / the Polish Library in Paris $=$ dans les fonds de la Société Historique et Littéraire Polonaise / Bibliothèque Polonaise de Paris = ze zbiorów Towarzystwa Historyczno-Literackiego / Biblioteki Polskiej w Paryżu, (współpr. A. Czarnocka, J. Davous, M.M. Grąbczewska, A. Długosz, M. Głodek, E. Niemirowicz, E. Rutkowska, J. Sapeta, E. Telma-Davous, K. Thomas, K. Žák), Paris 2010, [Album]; Chopin i jego malarz. Teofil Kwiatkowski (1809-1891): malarstwo i rysunek ze zbiorów Muzeum Narodowego w Warszawie i Biblioteki Polskiej w Paryżu = Chopin et son peintre: Teofil Kwiatkowski (1809-1891): peintures et dessins dans les collections du Musée national de Varsovie et de la Bibliothèque Polonaise de Paris, (oprac. K. Pijanowska, av. coll. A. Czarnocka, A. Rudzińska, tł. na jęz. franc. D. Karczewska, J. Ruszel, E. Stachurski, tł. na jęz. pol. J. Lemańska), Warszawa 2010, [Katalog dzieł]. Zob. dziennik wydarzeń kulturalnych THL/BPP, http://www.bibliotheque-polonaise-paris-shlp.fr/ [dostęp: 09.12.2009] zakładka menu pionowego Manifestations culturelles.

103 Warto zaznaczyć, iż IPN w 2013 r. przyznał BPP nagrodę „Kustosz Pamięci Narodowej” w dowód uznania czynnego udziału w upamiętnianiu historii narodu polskiego w latach 1939-1989, a także za działalność publiczną zbieżną z celami Instytutu Pamięci Narodowej. Nagroda „Kustosz Pamięci Narodowej" przyznawana jest corocznie od 2002 r., https://ipn.gov.pl/pl/aktualnosci/konkursy-i-nagrody/nagroda-kustosz-pamieci/2013/24285,Biblioteka-Polska-w-Paryzu.html [dostęp: 29.04.2018] Ponadto, zbiory THL: BPP i Muzeum Adama Mickiewicza w Paryżu zostały wpisane na światową listę programu „Pamięć Świata” UNESCO w 2013 r., jako świadectwo jedynej w swoim rodzaju instytucji emigracyjnej, która przez 123 lata rozbiorów miała istotny wpływ na zachowanie tożsamości narodowej i wolę odzyskania przez Polskę niepodległości, http://www.unesco.pl/komunikacja-i-informacja/ pamiec-swiata/polskie-obiekty-na-liscie-pamieci-swiata [dostęp: 29.04.2018]. 
sto dostosowując się do aktualnych potrzeb czy wymagań, wykorzystując różne doświadczenia, zdobyte w uprzednio wykonywanych zawodach czy pełnionych dotychczas funkcjach i rolach ${ }^{104}$. Dużą zaletą pracy w BPP były zróżnicowane zajęcia. Sytuacja taka sprawiała, że praca samodzielna, zespołowa czy z czytelnikami była interesująca, przyniosła mi wiele satysfakcji i osobistego rozwoju. Dodatkowo ceniłam sobie bezpośredni kontakt z czytelnikami francuskojęzycznymi oraz z polską emigracją lat 80 . i wcześniejszą - nierzadko już wielopokoleniową - gromadzącą się przy Polskiej Misji Katolickiej we Francji / La Mission Catholique Polonaise en France (https://www.mission-catholique-polonaise.net/) przy 263 bis, rue Saint Honoré w Paryżu. Roczne doświadczenie zawodowe w BPP w zakresie wymiany międzybibliotecznej: współpraca i kooperacja z bibliotekarzami, darczyńcami czy wydawnictwami - w moim odczuciu i po otrzymaniu zwrotnego potwierdzenia - udało się zrealizować z obustronną korzyścią i zadowoleniem. Traktując podjęty trud i wysiłek dla dobra zbiorów bibliotecznych jako misję wobec polskiego dziedzictwa kulturowego, pragnę wyrazić swoją wdzięczność i podziękowanie władzom PAU, THL i dyrekcji Biblioteki za okazane mi zaufanie i wyrażane słowa uznania.

Żywię nadzieję, że wkład pracy archiwistów, historyków sztuki i bibliotekarzy w roku 2008/2009 przyczynił się do tego, aby Biblioteka Polska w Paryżu stała się przestrzenią nowoczesną, otwartą i przyjazną dla użytkowników, służącą informacji naukowej, gromadzeniu, opracowaniu i udostępnianiu zbiorów polskiego dziedzictwa narodowego poza granicami kraju na wysokich standardach.

\section{POMOST BILATERALNEJ WSPÓŁPRACY KULTURALNEJ BPP: FRANCJA - POLSKA}

Oprócz wymienionych już kontaktów lokalnych we Francji, z instytucjami naukowymi i akademickimi w Polsce ${ }^{105}$, w warszawskiej Akademii Sztuk Pięk-

104 Zob. opis doświadczeń zawodowych innego pracownika w BPP z tego czasu. D. ADAmowicz, Biblioteka Polska w Paryżu (Bibliothèque Polonaise de Paris), „Tytuł Ujednolicony” 2012, nr 8, s. 18-22, https://issuu.com/nukat/docs/tu.8.2012 [dostęp: 29.04.2018].

105 BPP w ramach kontaktów z młodymi przyjęła około 40 uczniów wraz z nauczycielami z Polski w dn. 9 maja 2009 r. Młodzież szkolna zwiedziła Bibliotekę Polską, muzea oraz zapoznała się z historią polskiej emigracji. BPP przeprowadziła także zajęcia edukacyjno-oświatowe; występuje w roli Patrona Gimnazjum Zespołu Szkół w Świątnikach Górnych, które przyjęło imię Biblioteki Polskiej w Paryżu. Po powrocie do Polski młodzież szkolna nadesłała wspaniale własnoręcznie wykonane karty z podziękowaniami. Wówczas w skład Zespołu Szkół w Świątnikach Górnych wchodziło Gimnazjum im. Biblioteki Polskiej w Paryżu i Liceum Ogólnokształcące o profilu mundurowym, 
nych została zorganizowana wystawa prac Bolesława Biegasa pt. „Nawet Rodin by na to nie wpadł" w dniu 25 września 2009 r. przez ASP w Warszawie, Muzeum Mazowieckie w Płocku, Polskie Towarzystwo Historyczno-Literackie / Bibliotekę Polską w Paryżu. Towarzyszyło jej wstępne wystąpienie reprezentantów każdego ze współorganizatorów oraz kolekcjonerów prac artysty. Bibliotekę Polską reprezentowała dyrektor BPP - Danuta Dubois. Należy zaznaczyć, że BPP występując jako prawny spadkobierca prac z pracowni Biegasa, przyjęła na siebie zadanie reprezentowania i popularyzacji dzieł sztuki tego, można byłoby powiedzieć, mało znanego i niedocenionego do tej pory artysty.

Pobyt w Paryżu był sposobnością do poznania środowiska lokalnego oraz odwiedzin i visite guidée w Bibliotece Narodowej Francji / Bibliothèque nationale de France / BnF (http://www.bnf.fr)), Archiwum Narodowym w Paryżu / Archives Nationales, Le site de Paris (http://www.archivesnationales.culture.gouv.fr/anparis/) i bibliotekach miejskich, które - moim zdaniem - funkcjonują według polskich standardów bibliotek uniwersyteckich. Spotkałam miejskie biblioteki specjalistyczne efektywnie i z klimatem połączone z innymi zabudowaniami przestrzeni miejskiej, w których czytelnik wyrabiał plastikową kartę magnetyczną ważną we wszystkich miejskich bibliotekach danego regionu (z możliwością wykonania na miejscu kopii materiałów źródłowych), książki ustawione były w wolnym dostępie, zaopatrzone w paski magnetyczne, które bibliotekarz odmagnesowywał przed wyjściem czytelnika, i oczywiście bramki przy wejściu/wyjściu z bibliotek. Moją uwagę przyciągały liczne stanowiska internetowe z dostępem do katalogów elektronicznych, gustownie wkomponowane w architekturę i wystrój pomieszczeń bibliotecznych. Oprócz zdobytych doświadczeń zawodowych, korzystałam z okazji, aby nacieszyć oczy otaczającymi mnie dziełami sztuki i kultury w Paryżu (https:// www.monuments-nationaux.fr/) oraz bogactwem przyrody innych rejonów Francji.

Perspektywa trzech ostatnich wieków rysuje zróżnicowany motyw wyjazdu i pobytu Polaków na obcej ziemi ${ }^{106}$ w każdym okresie historycznym. Z biografii

http://www.swiatniki-gorne.pl/page/247, zespoly-szkol.html?id=3 [dostęp: 29.10.2009]. Por. Uchwała Nr XLIII/348/2017 Rady Miejskiej w Świątnikach Górnych z dnia 27 listopada 2017 r. w sprawie: nadania Statutu Szkole Podstawowej nr 2 w Świątnikach Górnych im. Biblioteki Polskiej w Paryżu, http://www.sp2-swiatniki.pl/index.php/dokumenty-szkolne [dostęp: 29.04.2018].

${ }^{106}$ Biblioteka Polska aktywnie uczestniczy z życiu paryskiej społeczności lokalnej. Nie tylko paryskiej, bo francuskiej także. Od kilku lat, co roku, Biblioteka Polska w Paryżu przygotowuje program specjalny na przyjęcie gości z okazji obchodów Fête de la musique / Święto Muzyki, Nuit européenne des musées / Europejska Noc Muzeów. Por. La Nuit européenne des musées, 16 maja 2009 r., http:// www.bibliotheque-polonaise-paris-shlp.fr/index.php?id_page=20382 [dostęp: 29.10.2009]. Książnica polonijna planuje włączyć się w Journées Européennes du Patrimoine / Europejskie Dni Dziedzictwa Kulturowego, które przypadnie na dzień 19 września i odbędzie się już po moim wyjeździe 
osób wynika, że historia może ludzi - wbrew ich woli i decyzji - od siebie oddalać, ale może też i zbliżać, choć czasami - już po latach, nie ich samych, bo odeszli, ale poprzez dobro czy twórczość, którą po sobie pozostawili.

\section{BIBLIOGRAFIA}

Adamowicz D., Biblioteka Polska w Paryżu (Bibliothèque Polonaise de Paris), „Tytuł Ujednolicony" 2012, nr 8, s. 18-22, https://issuu.com/nukat/docs/tu.8.2012 [dostęp: 29.04.2018].

Baza Biogramów Biblioteki Jagiellońskiej, http://www.bj.uj.edu.pl/biogramy/szukaj-biogramow [dostęp: 29.04.2018].

Baza: [BPP] Fond Ancien, http://193.0.122.72/egi-bin//makwww.exe?BM=1 [dostęp: 29.04.2018].

Biblioteka Polska w Paryżu - skarbnica kultury narodowej: materiały z konferencji zorganizowanej przez Komisję Spraw Emigracji i Łączności z Polakami za Granicą, Dyskusja, 4 listopada 2014, Warszawa: Kancelaria Senatu 2014, s. 51-67 (dokument elektroniczny).

Biblioteka Polska w Paryżu w NUKAT, http://www.ebib.info/content/view/1593/202/ [dostęp: 29.10.2009].

BŁoŃSKI P., Témoignages. Grand frère fidèle [Jean Offredo - przyp. aut.], „6, quai d'Orléans d'Orléans: lettre de la Société Historique et Littéraire Polonaise et de la Bibliothèque Polonaise de Paris" 2012, nr 16, s. 2, http://www.bibliotheque-polonaise-paris-shlp.fr/ medias/quai_16_web_2.pdf [dostęp: 29.04.2018].

ByczKowska Z., Dublety Biblioteki Polskiej w Paryżu, „Biuletyn Informacyjny Biblioteki Narodowej" 2000, nr 4, s. 26-28.

Cel i Ustawy, Towarzystwo Paryzkie Lekarzy Polskich, Cel i Ustawa, Paryż, dn. 10 kwietnia 1858 roku, Zbiory BPP, sygn. 26514 II (1-6).

Chopin i jego malarz: Teofil Kwiatkowski (1809-1891): malarstwo i rysunek ze zbiorów Muzeum Narodowego w Warszawie i Biblioteki Polskiej w Paryżu $=$ Chopin et son peintre: Teofil Kwiatkowski (1809-1891): peintures et dessins dans les collections du Musée national de Varsovie et de la Bibliothèque Polonaise de Paris, oprac. K. Pijanowska, av. coll. A. Czarnocka, A. Rudzińska, tł. na jęz. franc. D. Karczewska, J. Ruszel, E. Stachurski, tł. na jęz. pol. J. Lemańska, Warszawa: Muzeum Narodowe w Warszawie 2010, Varsovie: Musée national de Varsovie 2010, [Katalog dzieł].

Chmielewski W., W trosce o narodowy i niezależny charakter Biblioteki Polskiej w Paryżu w czasie drugiej wojny światowej, „Rocznik Komisji Nauk Pedagogicznych” 66(2013), s. 15-32.

z Paryża. Przypuszczam, że jak zwykle, specjalna okazja przyciągnie wiele osób, niekoniecznie dlatego, że są Polakami lub ich potomkami, ale że będą ciekawe, co się kryje za wysokimi, drewnianymi i dotkniętymi zrębem czasu wrotami. 
Chopiniana in the collections of the Polish Historical and Literary Society / the Polish Library in Paris = dans les fonds de la Société Historique et Littéraire Polonaise / Bibliothèque Polonaise de Paris = ze zbiorów Towarzystwa Historyczno-Literackiego / Biblioteki Polskiej w Paryżu, współpr. A. Czarnocka, J. Davous, M.M. Grąbczewska, A. Długosz, M. Głodek, E. Niemirowicz, E. Rutkowska, J. Sapeta, E. Telma-Davous, K. Thomas, K. Žák, Paris: Société Historique et Littéraire Polonaise / Bibliothèque Polonaise de Paris 2010, [Album].

Czarnocka A., Kolekcje artystyczne Biblioteki Polskiej w Paryżu, http://www.bibliotheque-polonaise-paris-shlp.fr/medias/TEKSTACPL.pdf [dostęp: 29.10.2009].

Czarnocka A., Kolekcje artystyczne Biblioteki Polskiej w Paryżu, 2012, [w:] Towarzystwo Historyczno-Literackie, Biblioteka Polska w Paryżu: zarys historii i prezentacja zbiorów, red. W. Kordaczuk, E. Kosieradzka, E. Rutkowska, Paryż: Société Historique et Littéraire Polonaise 2014, Warszawa: Muzeum Literatury im. Adama Mickiewicza w Warszawie 2014, s. 174-177.

ĆwIK F.L., Biblioteka Polska w Paryżu: dziwne zwolnienia, „Nasz Dziennik” (Warszawa) 2002, nr 10, s. 10.

Evin F., Dernier round pour sauver l'hôtel Lambert, joyau de XVII ${ }^{e}$, „Le Monde” 8-9 mars 2009, s. 18.

Evin F., Des Qataris un peu trop entreprenants. La famille de l'émir du Qatar a acheté en 2007 l'hôtel Lambert, sur l'île Saint-Louis, à Paris. Elle veut y faire réaliser de grands travaux: parking, ascenseurs... L'Etat, décisionnaire, y est favorable, „Le Monde” 20 décembre 2008, s. 3.

Evin F., Feu vert sous réserves à la réhabilitation de l'hôtel Lambert, „Le Monde” 12 mars 2009, s. 22.

Evin F., Hôtel Lambert, suivez le guide, „Le Monde” 18-19 janvier 2009, s. 21.

Evin F., M. Delanoë refuse la renovation de l'hôtel Lambert. Le projet de la famille de l'émir du Qatar attise les tensions entre la Ville et l'Etat, „Le Monde” 25 décembre 2008, s. 18.

GaŁkowski A., Krasowska H., Biblioteka Polska w Paryżu - przegląd historiografii, „Nauka Polska. Jej potrzeby, organizacja i rozwój”, Rocznik Kasy im. Józefa Mianowskiego Fundacja Popierania Nauki (Warszawa) 24(2015), s. 105-119.

GŁodeK M., Narodowy Program Rozwoju Humanistyki szansą dla Biblioteki Polskiej w Paryżu, „6, quai d'Orléans: pismo informacyjne Towarzystwa Historyczno-Literackiego" 2014, nr 18, s. 21-22, http://www.bibliotheque-polonaise-paris-shlp.fr/medias/quai18PL_2.pdf [dostęp: 29.04.2018].

GrąBCZEWSKA M.M., „Miscellanea photographica”: narodziny języka fotografii, „Teksty Drugie" 2013, nr 4, s. 13-29.

GrąBCZEwSKa M.M., Powstanie i historia dagerotypowych wizerunków Fryderyka Chopina - nowe ustalenia, „Muzyka” 2008, nr 3, s. 75-86.

GrąBCZewsKa M.M., Zbiór dagerotypów Biblioteki Polskiej w Paryżu, „Rocznik Historii Sztuki" 32(2007), s. 125-154.

Heruday-KiefczewsKa M., Archiwum Stowarzyszenia Solidarité France-Pologne w zbiorach Biblioteki Polskiej w Paryżu, „Folia Toruniensia” 2017, nr 17, s. 175-187. 
Hôtel Lambert : la polémique enfle entre M. Delanoë et $\mathrm{M}^{\mathrm{me}}$ Albanel, „Le Monde” 26 décembre 2008, s. 15.

IgnaczaK P., Muzea w Bibliotece Polskiej w Paryżu, „Muzealnictwo” 2016, nr 57, s. 226233.

Instytucja „Czci i Chleba”. (Akt założenia, sprawozdania ...), Paryż 1862-1882, Zbiory BPP, sygn. 41140, (dep. BP w ML), [za:] Skarby kultury polskiej ze zbiorów Biblioteki Polskiej w Paryżu, Warszawa 2004, s. [25] (s.n.).

Instytut Pamięci Narodowej. Nagroda Kustosz Pamięci Narodowej 2013, https://ipn.gov.pl/ pl/aktualnosci/konkursy-i-nagrody/nagroda-kustosz-pamieci/2013/24285,Biblioteka-Polska-w-Paryzu.html [dostęp: 29.04.2018].

Inventaire des Archives de l'Association Solidarité France-Pologne 1980-2004. Inwentarz Archiwum Stowarzyszenia Solidarité France Pologne 1980-2004, oprac. M. Heruday-Kiełczewska, Paris: Association Solidarité France Pologne: Sociétè Historique et Littéraire Polonaise 2013.

KALCZYŃSKA M., Refleksje z pobytu na stypendium naukowym w Bibliotece Polskiej w Paryżu, [2014], http://www.ebib.pl/2009/105/a.php?kalczynska [dostęp: 29.04.2018].

Kania A., Domalewska D., Spotkanie Dyrektorów i Bibliotekarzy Systemowych Bibliotek współtworzących NUKAT [w BUW, Warszawa, 5 grudnia 2014 r.], https://bg.uek. krakow.pl/biblioteka/biuletyn/artykuly.php?Strona $=$ Art $\&$ Wybor $=44 \& A r t=k s \_n u k a t$ [dostęp: 29.04.2018].

Katalog elektroniczny BPP, https://katalogkrak.cyfronet.pl/search/query?theme=BPP [dostęp: 29.04.2018].

KęSICKA H., Międzynarodowa wymiana materiałów bibliotecznych, „Biuletyn Informacyjny Biblioteki Narodowej” 2000, nr 4, s. 17-20.

KŁossowski A., Instytucja spełnionej nadziei: Paryska Libella i Galeria Lambert Zofii i Kazimierza Romanowiczów: [katalog] wystawy 6 grudnia 1994 - 15 stycznia 1995, Pałac Rzeczypospolitej, Warszawa: Biblioteka Narodowa 1994/1995, s. 35, [za:] B. KonopKA, Bibliothèque Polonaise de Paris / Biblioteka Polska w Paryżu 1993/2012, Paris: La Société Historique et Littéraire Polonaise 2013.

Krakowski Zespół Biblioteczny (KZB), http://www.kzb.krakow.pl/index.php?p=kzb [dostęp: 29.04.2018].

Kulecki M., Sprawozdanie z prac archiwalnych w Bibliotece Polskiej w Paryżu, „Miscellanea Historico-Archivistica" 17(2010), s. 263-265.

Leszek Talko (1916-2003): o Bibliotece Polskiej w Paryżu, rozmowę przeprowadził A. Gałkowski [z początku stycznia 2000 r.], „Zeszyty Historyczne / Instytut Literacki” 2003, z. 146, s. 120-136.

L'hôtel Lambert: le grand voisin, „6, quai d'Orléans: lettre de la Société Historique et Littéraire Polonaise et de la Bibliothèque Polonaise de Paris" 2008, nr 11, s. 4-8, http://www. bibliotheque-polonaise-paris-shlp.fr/medias/biuletyn11.pdf [dostęp: 29.10.2009].

Lubicz-ZALeski K.P., Aneks. Historia zarządzania Biblioteką Polską w Paryżu, Paryż 2013, [w:] Towarzystwo Historyczno-Literackie, Biblioteka Polska w Paryżu: zarys historii i prezentacja zbiorów, red. W. Kordaczuk, E. Kosieradzka, E. Rutkowska, Paryż: Socié- 
té Historique et Littéraire Polonaise 2014, Warszawa: Muzeum Literatury im. Adama Mickiewicza w Warszawie 2014, s. 15-16.

Lubicz-Zaleski K.P., Biblioteka Polska w Paryżu, tł. z jęz. franc. K. Rutkowski, http:// www.bibliotheque-polonaise-paris-shlp.fr/medias/articleCPZtraductionpolonaise.pdf [dostęp: 29.10.2009].

Lubicz-ZALeski K.P., Towarzystwo Historyczno-Literackie i Biblioteka Polska w Paryżu, 2004 i 2012, [w:] Towarzystwo Historyczno-Literackie, Biblioteka Polska w Paryżu: zarys historii i prezentacja zbiorów, red. W. Kordaczuk, E. Kosieradzka, E. Rutkowska, Paryż: Société Historique et Littéraire Polonaise 2014, Warszawa: Muzeum Literatury im. Adama Mickiewicza w Warszawie 2014, s. 7-14.

ŁASKARZEWSKa H., Wojenne losy części zbiorów paryskiej Biblioteki Narodowej, [w:] Towarzystwo Historyczno-Literackie, Biblioteka Polska w Paryżu: zarys historii i prezentacja zbiorów, red. W. Kordaczuk, E. Kosieradzka, E. Rutkowska, Paryż: Société Historique et Littéraire Polonaise 2014, Warszawa: Muzeum Literatury im. Adama Mickiewicza w Warszawie 2014, s. 101-103.

MARKIEWICZ Z., Zygmunt Lubicz-Zaleski (29 września 1882 - 15 grudnia 1967) [nekrolog], „Pamiętnik Literacki”. Czasopismo kwartalne poświęcone historii i krytyce literatury polskiej 1969, nr 1, s. 413-414.

Matuszewska M., Biblioteka Polska jest otwarta dla czytelników, „Gazeta Wrocławska” 18 grudnia 2010, https://gazetawroclawska.pl/biblioteka-polska-jest-otwarta-dla-czytelnikow/ar/346947 [dostęp: 29.04.2018].

MĘCLEWSKA M., Zbiór rzeczy narodowych. Dawne i nowe kolekcje numizmatyczne Biblioteki Polskiej w Paryżu, [w:] Towarzystwo Historyczno-Literackie, Biblioteka Polska w Paryżu: zarys historii i prezentacja zbiorów, red. W. Kordaczuk, E. Kosieradzka, E. Rutkowska, Paryż: Société Historique et Littéraire Polonaise 2014, Warszawa: Muzeum Literatury im. Adama Mickiewicza w Warszawie 2014, s. 301-308.

Michalewicz A., Współpraca Polskiej Akademii Umiejętności z Towarzystwem Historyczno-Literackim, [w:] Wspólna sprawa. Studia i materiały do dziejów emigracji polskiej we Francji, Kraków: PAU 2017, s. 159-169.

Mignot C., Pour l'hôtel Lambert, faites encore un effort, Monsieur l'architecte en chef! Le plus discutable dans cette réhabilitation est le manque de bon sens patrimonial, „Le Monde" 24 février 2009, s. 17.

Miler J., Biblioteka Polska w Paryżu na tle polskich instytucji emigracyjnych, [w:] Biblioteka Polska w Paryżu - skarbnica kultury narodowej: materiały z konferencji zorganizowanej przez Komisję Spraw Emigracji i Łączności z Polakami za Granicą, 4 listopada 2014, Warszawa: Kancelaria Senatu 2014, s. 46-50 (dokument elektroniczny).

Narodowy Uniwersalny Katalog Centralny NUKAT, http://www.nukat.edu.pl/ [dostęp: 29.10.2009].

NiewęıowsKi A., Brève histoire de l'Hôtel 6, quai d'Orléans, [w:] Bibliothèque Polonaise de Paris, colloque de 20-21 septembre 2004, réd. M. Stęplewska, Cracovie : L'Académie Polonaise des Sciences et des Lettres 2008, s. 88-95.

NiewęGlowski A., Salon Chopina, „Cenne, Bezcenne / Utracone” 2011, nr 2, s. 14-15. 
Organigramme THLP/BPP od 2013 r., http://www.bibliotheque-polonaise-paris-shlp.fr/medias/ORGANIGRAMME_2015_2.pdf [dostęp: 29.04.2018].

Pamiętnik Towarzystwa Nauk Ścisłych w Paryżu, t. 10, Paryż 1878, Zbiory BPP, sygn. 001878, (dep. BP w ML), [za:] Skarby kultury polskiej ze zbiorów Biblioteki Polskiej w Paryżu, Warszawa 2004, s. [25] (s.n.).

Pezda J., Historia Biblioteki Polskiej w Paryżu w latach 1838-1893, Kraków: Towarzystwo Wydawnicze „Historia Iagiellonica” 2013.

Pezda J., Suplement do tomu V Katalogu Rękopisów Biblioteki Polskiej w Paryżu. Stowarzyszenie podatkowe - Instytucja „Czci i Chleba”, sygn. 756-759, [w:] Wspólna sprawa. Studia i materiały do dziejów emigracji polskiej we Francji, Kraków: PAU 2017, s. 119-133.

Pokaz zbiorów z BP z Paryża i POSK z Londynu konserwowanych w BN, http://www. bn.org.pl/aktualnosci/1351-pokaz-zbiorow-z-paryza-i-londynu-konserwowanych-w-bn.html [dostęp: 19.11.2009].

Polska Misja Katolicka we Francji, https://www.mission-catholique-polonaise.net/ [dostęp: 29.07.2018].

PuŁaski F., Biblioteka Polska w Paryżu w latach 1893-1948, Paryż 1948.

PYrzowsKa L., Projekt badawczy Polskiej Akademii Umiejętności Opracowanie katalogów XIX-wiecznych druków wydanych na emigracji i ziemiach polskich za granicą ze zbiorów Biblioteki Polskiej i Towarzystwa Historyczno-Literackiego w Paryżu, [w:] Wspólna sprawa. Studia i materiały do dziejów emigracji polskiej we Francji, Kraków: PAU 2017, s. 177-181.

RaPACKI M., Otwarto Bibliotekę Polską w Paryżu, Gazeta.pl/Wiadomości, 28.09.2004, http://wiadomosci.gazeta.pl/wiadomosci/1,114873,2310365.html [dostęp: 29.10.2009].

RutKowska E., Wiatyk na wieczność. O archiwach rękopiśmiennych Biblioteki Polskiej w Paryżu, 2008 i 2011, [w:] Towarzystwo Historyczno-Literackie, Biblioteka Polska w Paryżu: zarys historii i prezentacja zbiorów, red. W. Kordaczuk, E. Kosieradzka, E. Rutkowska, Paryż: Société Historique et Littéraire Polonaise 2014, Warszawa: Muzeum Literatury im. Adama Mickiewicza w Warszawie 2014, s. 19-22.

RutKowska E., Wiatyk na wieczność. O zbiorach rękopiśmiennych Biblioteki Polskiej w Paryżu, http://www.bibliotheque-polonaise-paris-shlp.fr/medias/TEKSTERPL.pdf [dostęp: 29.10.2009].

Seroka K., Biblioteka Polska w Paryżu (1838-1871): studium bibliologiczne, Warszawa: Grupa Cogito 2017.

SEROKA K., Biblioteka Polska w Paryżu - polskie miejsce pamięci w Paryżu. Referat na konferencji naukowej „Miejsca pamięci w świadomości współczesnego człowieka” w dn. 10 maja 2013 r. na Uniwersytecie Mikołaja Kopernika w Toruniu, Toruń 2014.

SiomkajŁo A., Największa na Zachodzie - Biblioteka Polska w Paryżu, „Studia Polonijne” 26(2005), s. 215-219.

Société Historique et Littéraire Polonaise / Bibliothèque Polonaise de Paris $=$ SHLP/BPP = Polskie Towarzystwo Historyczno-Literackie / Biblioteka Polska w Paryżu $=$ THLP/ BPP, http://www.bibliotheque-polonaise-paris-shlp.fr/ [dostęp: 29.04.2018]. 
Sprawozdanie Biblioteki Narodowej za rok 2008, Warszawa: Biblioteka Narodowa 2009, http://www.bn.org.pl/download/document/1241790645.pdf [dostęp: 09.12.2009].

Sprawozdanie Biblioteki Narodowej za rok 2009, Warszawa: Biblioteka Narodowa 2010, https:/www.bn.org.pl/download/document/1275916984.pdf [dostęp: 29.04.2018].

Stała Konferencja Muzeów, Archiwów i Bibliotek Polskich na Zachodzie (MABPZ), http:// mabpz.org/ [dostęp: 29.04.2018].

Suchowiejko R., Spuścizna Michała Spisaka (1914-1965) w Paryżu: nowe źródła do badań nad twórczością kompozytora, „Muzyka” 2015, nr 2, s. 55-62, Aneks: wykaz utworów M. Spisaka, s. 63-97.

TALKo L., Biblioteka Polska w Paryżu, rozmowę przeprowadziła A. Ciesielska-Ribard [14 stycznia 1999 r.], „Roczniki. PAN. Stacja Naukowa w Paryżu” 2(2000), s. 161-166.

Towarzystwo Historyczno-Literackie, Biblioteka Polska w Paryżu: zarys historii i prezentacja zbiorów, red. W. Kordaczuk, E. Kosieradzka, E. Rutkowska, Paryż: Société Historique et Littéraire Polonaise 2014, Warszawa: Muzeum Literatury im. Adama Mickiewicza w Warszawie 2014.

Towarzystwo Przyjaciół Biblioteki Polskiej w Paryżu, http://www.przyjacielebpp.org/ [dostęp: 29.04.2018].

Uchwała Nr XLIII/348/2017 Rady Miejskiej w Świątnikach Górnych z dn. 27 listopada 2017 r. w sprawie: nadania Statutu Szkole Podstawowej nr 2 w Świątnikach Górnych im. Biblioteki Polskiej w Paryżu, http://www.sp2-swiatniki.pl/index.php/dokumenty-szkolne [dostęp: 29.04.2018].

Ustawa Towarzystwa Paryzkiego Lekarzy Polskich, Paryż, dn. 1 marca 1865 roku, Zbiory BPP, sygn. 17818 III.

Ustawy Towarzystwa Filharmonicznego Polskiego w Paryżu, Paryż 1880, Zbiory BPP, sygn. 93407, (dep. BP w ML), [za:] Skarby kultury polskiej ze zbiorów Biblioteki Polskiej w Paryżu, Warszawa 2004, s. [25] (s.n.).

WAGNeR A., By chronić i zdobić: o oprawach, superekslibrisach i ekslibrisach w Bibliotece Polskiej w Paryżu, Paryż-Toruń: Wydawnictwo Naukowe Uniwersytetu Mikołaja Kopernika 2014.

WAGNER A., Najpiękniejsze superekslibrisy i ekslibrisy XVI-XX wieku w zbiorach Biblioteki Polskiej w Paryżu, „Tekstualia” 2013, nr 3, s. 191-200.

Wrotnowska D., Słownik artystów polskich emigracji 1830 roku: malarzy, grafików, litografów i rytowników, Paryż: Ecole de Louvre 1948.

Z dala od orkiestry, reż. i scen. Rafael Lewandowski, prod. Vertigo, Zygmunt Zaleski Stichting, Polska, 2017.

ZaHORSKI W., Charakterystyka księgozbioru Biblioteki Polskiej w Paryżu, http://www. bibliotheque-polonaise-paris-shlp.fr/medias/TEKSTW.ZPL.pdf [dostęp: 29.10.2009].

ZAHORSKi W., Charakterystyka księgozbioru Biblioteki Polskiej w Paryżu, [w:] Towarzystwo Historyczno-Literackie, Biblioteka Polska w Paryżu: zarys historii i prezentacja zbiorów, red. W. Kordaczuk, E. Kosieradzka, E. Rutkowska, Paryż: Société Historique et Littéraire Polonaise 2014, Warszawa: Muzeum Literatury im. Adama Mickiewicza w Warszawie 2014, s. 95-97. 
ZAHORSKI W., Zygmunt Lubicz-Zaleski w archiwach Towarzystwa Historyczno-Literackiego i Biblioteki Polskiej w Paryżu, [w:] Politycy i artyści: materiały XXXVIII Sesji Stałej Konferencji Muzeów, Archiwów i Bibliotek Polskich na Zachodzie, Londyn: Polski Ośrodek Społeczno-Kulturalny, 14-18 września 2016, komitet red. D. Platt, E.K. Hoffman-Jędruch, K.R. Jaworska, J. Kułakowska-Lis, M. Machlejd, Londyn: Biblioteka Polska POSK; Warszawa: Muzeum Historii Polski, cop. 2017, s. 76-80.

ZALESKI C.P., Hommage à Jean Offredo, „6, quai d'Orléans: lettre de la Société Historique et Littéraire Polonaise et de la Bibliothèque Polonaise de Paris" 2012, nr 16, s. 1, http://www. bibliotheque-polonaise-paris-shlp.fr/medias/quai_16_web_2.pdf [dostęp: 29.04.2018].

ZALESKI K.P., Towarzystwo Historyczno-Literackie i Biblioteka Polska w Paryżu - historia i teraźniejszość, [w:] Biblioteka Polska w Paryżu - skarbnica kultury narodowej: materiały z konferencji zorganizowanej przez Komisję Spraw Emigracji i Łączności z Polakami za Granicą, 4 listopada 2014, Warszawa: Kancelaria Senatu 2014, s. 19-35 (dokument elektroniczny).

ZALESKI K.P., Wspomnienie o Ewie Niemirowicz, „6, quai d'Orléans: pismo informacyjne Towarzystwa Historyczno-Literackiego" 2015, nr 19, s. 2, http://www.bibliotheque-polonaise-paris-shlp.fr/medias/6QUAI19PL_web_2.pdf [dostęp: 29.04.2018].

ZALESKI K.P., Wspomnienie o Jean-Pierre Mustelier, „6, quai d'Orléans: pismo informacyjne Towarzystwa Historyczno-Literackiego" 2014, nr 18, s. 2, http://www.bibliotheque-polonaise-paris-shlp.fr/medias/quai18PL_2.pdf [dostęp: 29.04.2018].

Zeskanowany katalog kartkowy BPP, http://62.23.96.204:9000/webconsultation/skins/default_gray/findex.jsp [dostęp: 29.04.2018].

Zespół Szkół w Świątnikach Górnych: Gimnazjum im. Biblioteki Polskiej w Paryżu, Liceum Ogólnokształcące o profilu mundurowym, http://www.swiatniki-gorne.pl/ page/247,zespoly-szkol.html?id=3 [dostęp: 29.10.2009].

ZIEJKa F., Biblioteka Polska w Paryżu - skarbnica kultury narodowej, [w:] Biblioteka Polska w Paryżu - skarbnica kultury narodowej: materiały z konferencji zorganizowanej przez Komisję Spraw Emigracji i Łączności z Polakami za Granicą, 4 listopada 2014, Warszawa: Kancelaria Senatu 2014, s. 36-45 (dokument elektroniczny).

ZIEJKa F., Skarby kultury polskiej na Wyspie Świętego Ludwika w Paryżu, „Acta Universitatis Wratislaviensis". Prace Literackie 2015, nr 55, s. 17-33.

Zygmunt Zaleski Stichting, https://www.zygmuntzaleskistichting.com/film [dostęp: 29.04. 2018].

Żarnowski J., PuŁaski F., Chowaniec Cz., La Bibliothèque Polonaise de Paris sous l'occupation allemande (1940-1944) = Biblioteka Polska w Paryżu pod okupacją niemiecką (1940-1944), oprac. W. Zahorski, [w:] La vie quotidienne sur l'île Saint-Louis au $\mathrm{XIX}^{\mathrm{e}}$ et au début du XX $\mathrm{XX}^{\mathrm{e}}$ siècle dans les collections de la Société Historique et Littéraire Polonaise / Bibliothèque Polonaise de Paris = Życie codzienne na Wyspie św. Ludwika w XIX i na początku XX wieku w kolekcjach Towarzystwa Historyczno-Literackiego / Biblioteki Polskiej w Paryżu, trad. A. Czarnocka, V. Demidot, W. Zahorski, Paris: Société Historique et Littéraire Polonaise - Bibliothèque Polonaise 2017, s. $22-52$. 


\section{TOWARZYSTWO HISTORYCZNO-LITERACKIE I BIBLIOTEKA POLSKA W PARYŻU: DOŚWIADCZENIE WYMIANY MIĘDZYBIBLIOTECZNEJ \\ W ROKU 2008/2009}

\section{Streszczenie}

W artykule przedstawiono historię Towarzystwa Historyczno-Literackiego / Biblioteki Polskiej w Paryżu znajdujących się na Wyspie Świętego Ludwika od momentu powołania przez Wielką Emigrację do czasów współczesnych. Opisowi poddano strukturę wewnętrzną Towarzystwa Historyczno-Literackiego i Biblioteki Polskiej oraz udostępniane zbiory: archiwa i rękopisy w Pracowni Zbiorów Specjalnych (jedynie naukowcom i badaczom), książki i czasopisma w Czytelni, zbiory artystyczne w Pracowni Kolekcji Artystycznych. Krótko omówiono mało znane wśród Polaków trzy muzea: Muzeum Adama Mickiewicza, Salon Fryderyka Chopina, Muzeum Bolesława Biegasa, stanowiące ekspozycje stałe integralnie wkomponowane w gmach Biblioteki Polskiej w Paryżu. Uwagę skupiono na własnych zawodowych doświadczeniach bibliotekarskich w Bibliotece Polskiej pod kątem dubletów i wymiany międzybibliotecznej w roku 2008/2009 i życiu codziennym, jakie w niej się toczyło. Równolegle do opisu THL/BPP sygnalizowano ówczesne losy pobliskiej rezydencji historycznej Hôtel Lambert, niegdyś należącej do rodu książąt Czartoryskich i stanowiącej polskie centrum kulturalno-polityczne. Zwrócono uwagę na przebieg debaty publicznej oraz sprzeciw francuskich środowisk konserwatorskich i Polonii francuskiej, która miała miejsce od grudnia 2008 do marca $2009 \mathrm{r}$. wobec planu przebudowy i modernizacji oryginalnej zabudowy Hotelu Lambert przez nowego właściciela.

Słowa kluczowe: Wyspa Świętego Ludwika; Wielka Emigracja; Towarzystwo Historyczno-Literackie; Biblioteka Polska w Paryżu; Hôtel Lambert; emigracja polska; biblioteka polska na Zachodzie; muzealnictwo; Muzeum Adama Mickiewicza; Salon Fryderyka Chopina; Muzeum Bolesława Biegasa; biblioteki polonijne; bibliotekarstwo; zbiory biblioteczne; gromadzenie zbiorów; wymiana międzybiblioteczna; Polonia we Francji

\section{TOWARZYSTWO HISTORYCZNO-LITERACKIE AND POLISH LIBRARY IN PARIS: EXPERIENCE IN TERMS OF INTERLIBRARY EXCHANGE IN 2008/2009}

\section{Sum mary}

The article presents the history of Towarzystwo Historyczno-Literackie / Polish Library in Paris located on St. Ludwik from the moment of establishing by the Great Emigration to modern times. The internal structure of the Historical-Literary Society and the Polish Library in Paris is described, as well as collections: books and magazines in the Reading Room, archives and manuscripts in the Special Collections Laboratory (only scientists and researchers), artistic 
collections in the Artistic Collections Laboratory. A brief description of the three unknown museums in Poland: the Adam Mickiewicz Museum, the Fryderyk Chopin Salon, the Bolesław Biegas Museum, constituting permanent exhibitions integrally incorporated into the building of the Polish Library in Paris. Attention was focused on their own professional library experience in the Polish Library in terms of interlibrary exchange in 2008/2009 and everyday life in it. Parallel to the description of THL / BPP, the then fate of the nearby historic residence, Hôtel Lambert, was once mentioned to the Czartoryski family and was a Polish cultural and political center. The article draws attention to the public debate and opposition of the French conservationist and French Polonia, which took place from December 2008 to March 2009, in view of the plan to reconstruct and modernize the original development of Hôtel Lambert by the new owner.

Key words: Island of St. Ludwik; Great Emigration; Historical and Literary Society; Polish Library in Paris; Hôtel Lambert; Polish emigration; Polish library in the West; museology; the Adam Mickiewicz Museum; the Fryderyk Chopin Salon; the Bolesław Biegas Museum; Polish library; librarianry; library collections; collection of collections; interlibrary exchange; Polonia in France

\section{SOCIÉTÉ HISTORIQUE ET LITTÉRAIRE POLONAISE ET BIBLIOTHÈQUE POLONAISE DE PARIS : L'EXPÉRIENCE D'ÉCHANGE ENTRE LES BIBLIOTHĖQUES DANS L'ANNÉE 2008/2009}

\section{Résumé}

Dans l'article est présentée l'histoire de la Société Historique-Littéraire Polonaise (SHLP) / la Bibliothèque Polonaise de Paris (BPP) sur l'île Saint-Louis depuis sa création par la Grande Emigration aux temps modernes. Sont également évoqués: la structure interne de la Société Historique et Littéraire Polonaise (SHLP), la Bibliothèque Polonaise de Paris et ses responsabilités, les fonds accessibles aux lecteurs comprenant livres et périodiques dans la Salle de Lecture, les archives et les manuscrits dans la Salle des Chercheurs ainsi que les fonds artistiques de la Collection Artistique. Il y est également évoquée la relation peu connue entre les trois Musées polonais: le Musée d'Adam Mickiewicz, le Salon de Frédéric Chopin, le Musée de Boleslas Biegas en tant qu'expositions permanentes et intégrales de la Bibliothèque Polonaise de Paris. L'article porte naturellement le soucis de l'expérience professionnelle propre des bibliothécaires de la Bibliothèque Polonaise de Paris (BPP) surtout dans le domaine des échanges des matériaux bibliothécaires de la vie quotidienne au cours de l'année 2008/2009. Parallèlement à la description de SHLP/BPP est relevée la situation de la résidence voisine de la famille Czartoryski Hôtel Lambert qui constituait autrefois le centre politique et culturel polonais. A ce propos, l'article se concentre sur le débat public et l'opposition entre la protestation de la communauté française des conservateurs du patrimoine et la communauté polonaise en France, qui a eu lieu de décembre 2008 à mars 2009 contre la modernisation de la construction originale et historique de l'Hôtel Lambert par son nouveau propriétaire. 
Mots clés : L'île Saint-Louis ; Grande Émigration ; Société Historique et Littéraire Polonaise (SHLP) ; la Bibliothèque Polonaise de Paris (BPP) ; l'Hôtel Lambert ; l'émigration polonaise ; la bibliothèque polonaise dans l'Ouest ; les musées ; Musée d'Adam Mickiewicz ; Salon de Frédéric Chopin ; Musée de Boleslas Biegas ; bibliothèques de Polonie ; collection de la bibliothèque; bibliothéconomie ; fonds de bibliothèque ; des livres doubles ; des impressions inutiles ; l'échange des materiaux bibliothécaire ; service des acquisitions et d'échange entre les bibliothèques ; Polonie en France ; la minorité polonaise en France 